\title{
Modelo de análise de populações de plantas daninhas resistentes a herbicidas
}

\author{
Henrique Sadao Kajino
}

Dissertação apresentada à Escola de Engenharia de São Carlos da Universidade de São Paulo, como parte dos requisitos para obtenção do título de Mestre em Ciências, Programa de Engenharia Elétrica.

ORIENTADORA: Profa. Dra. Vilma Alves de Oliveira 
AUTORIZO A REPRODUÇÃO E DIVULGAÇÃO TOTAL OU PARCIAL DESTE TRABALHO, POR QUALQUER MEIO CONVENCIONAL OU ELETRÔNICO, PARA FINS DE ESTUDO E PESQUISA, DESDE QUE CITADA A FONTE.

Ficha catalográfica preparada pela Seção de Tratamento da Informação do Serviço de Biblioteca - EESC/USP

\footnotetext{
$\mathrm{K} 13 \mathrm{~m}$ Kajino, Henrique Sadao.

Modelo de análise de populações de plantas daninhas resistentes a herbicidas. / Henrique Sadao Kajino ; orientador Vilma Alves de Oliveira. São Carlos, 2011.

Dissertação (Mestrado - Programa de Pós-Graduação em Engenharia Elétrica e Área de Concentração em Sistemas Dinâmicos)-- Escola de Engenharia de São Carlos da Universidade de São Paulo, 2011.

1. Modelos não lineares. 2. Resistência de plantas daninhas. 3. Herbicida. 4. Controle de planta daninha. 5. Dose-resposta. 6. Bidens subalternans. 7. Bidens pilosa. I. Título.
} 


\section{FOLHA DE JULGAMENTO}

Candidato: Bacharel HENRIQUE SADAO KAJINO

Título da dissertação: "Modelo de análise de populações de plantas daninhas resistentes a herbicidas".

Data da defesa: 30/09/2011:

\section{Comissão Julgadora:}

Profa. Titular Vilma Alves de Oliveira (Orientadora)

(Escola de Engenharia de São Carlos/EESC)

\section{Dr. Décio Karam}

(Empresa Brasileira de Pesquisa Agropecuária/EMBRAP)

Prof. Associado Pedro Jacob Christoffoleti

(Escola Superior de Agricultura Luiz de Queiroz/ESALQ)
Resultado:

ARRONADO
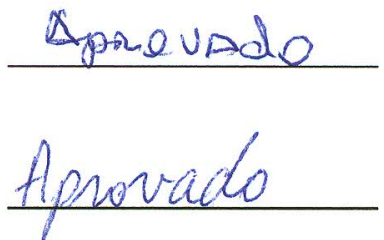

Coordenador do Programa de Pós-Graduação em Engenharia Elétrica:

Prof. Titular Denis Vinicius Coury

Presidente da Comissão de Pós-Graduação:

Prof. Associado Paulo Cesar Lima Segantine 



\section{HENRIQUE SADAO KAJINO}

\section{Modelo de análise de populações de plantas daninhas resistentes a herbicidas}

Dissertação apresentada à Escola de Engenharia de São Carlos da Universidade de São Paulo, como parte dos requisitos para obtenção do Título de Mestre em Ciências, Programa de Engenharia Elétrica.

Área de Concentração: Sistemas Dinâmicos

Orientador: Profa. Dra. Vilma Alves de Oliveira 
A todos que ajudaram a iluminar meu caminho com suas luzes. 
A consciência superior, que todos os dias está presente na minha vida.

A minha mãe, Leica, por tudo e mais um pouco.

A minha orientadora Profa. Dra. Vilma Alves de Oliveira, USP e CAPES/CNPq.

A todos os amigos, colegas e pessoas que surgiram na minha vida e me ajudaram. 


\section{Sumário}

Lista de Figuras $\quad$ xi

$\begin{array}{ll}\text { Lista de Tabelas } & \text { xv }\end{array}$

Resumo xvii

Abstract $\quad$ xix

1 Introdução 1

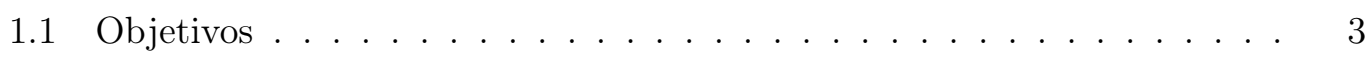

1.2 Organização do trabalho . . . . . . . . . . . . . . . 4

2 Revisão bibliográfica 5

2.1 Plantas daninhas . . . . . . . . . . . . . . . . . 5

2.1.1 Banco de sementes . . . . . . . . . . . . . . . . 6

2.1.2 Mecanismos de reprodução . . . . . . . . . . . . . . 6

2.2 Métodos de controle da população de plantas daninhas . . . . . . . . 7

2.3 Resistência como característica genética de plantas daninhas . . . . . . 9

2.3.1 Características que levam à resistência de toda uma população · 11

2.4 Metodologia de detecção de possíveis casos de resistência . . . . . . . 13

2.4 .1 Função dose-resposta . . . . . . . . . . . . . . . . . . . . . 14

3 Características dos principais modelos de resistência a herbicidas $\quad 17$

3.1 Primeiros trabalhos sobre a resistência a herbicidas . . . . . . . . . . . 17

3.2 Modelo de manejo de populações de plantas daninhas com resistência • 18

3.2.1 Submodelo do banco de sementes . . . . . . . . . . . . . 19

3.2.2 Submodelo de imigração de sementes . . . . . . . . . . . . . 19

3.2.3 Submodelo de germinação . . . . . . . . . . . . . . . . 20

3.2.4 Submodelo de plantas adultas . . . . . . . . . . . . . . . . 21

3.2.5 Submodelo de imigração de pólen . . . . . . . . . . . . . . 21 
3.2.6 Submodelo de produção de pólen . . . . . . . . . . . . . . . 21

3.2.7 Submodelo de reprodução . . . . . . . . . . . . . . . . . . . . . 22

3.2.8 Submodelo de produção de sementes . . . . . . . . . . . . 23

3.3 Modelo da resistência múltipla e modelo da resistência ao glifosato . . . 25

3.4 Modelo de evolução de resistência a pesticidas . . . . . . . . . . . . . . 28

3.5 Modelo de evolução através de pressão seletiva . . . . . . . . . . . . . . 30

4 Modelo proposto de análise de populações de plantas daninhas re$\begin{array}{ll}\text { sistentes a herbicidas } & 33\end{array}$

4.1 Concepção do modelo proposto . . . . . . . . . . . . . . . . . 33

4.1 .1 A recombinação genética . . . . . . . . . . . . . . . . 34

4.1.2 A eficácia da dose e o comportamento genético da população . . 35

4.2 Modelo proposto para um herbicida . . . . . . . . . . . . . 36

4.2.1 Submodelo de recombinação genética . . . . . . . . . . . . 36

4.2 .2 Submodelo de dose-resposta . . . . . . . . . . . . . . . . 40

4.2 .3 Submodelo populacional . . . . . . . . . . . . . . . . . 41

4.3 Modelo com segregação do banco de sementes em biótipos (MSBSB) . . 41

4.4 Modelo de características genéticas da população (MCGP) . . . . . . . 43

4.5 Modelo proposto para múltiplos herbicidas . . . . . . . . . . . . . . . . 44

5 Resultados de simulações $\quad 49$

5.1 Estudo de caso: Bidens subalternans . . . . . . . . . . . . . . 50

5.1 .1 Simulação do modelo proposto para um herbicida . . . . . . . . 51

5.1.2 Simulação do MSBSB e do MCGP para o herbicida nicosulfuron 52

5.2 Estudo de caso: Bidens pilosa . . . . . . . . . . . . . 53

5.2.1 Simulação do modelo proposto para um herbicida . . . . . . . . 54

5.2.2 Simulação MSBSB e do MCGP para o herbicida chlorimuron-ethyl 56

5.2 .3 Discussão . . . . . . . . . . . . . . . . . . . 56

5.3 Análise de equilíbrios . . . . . . . . . . . . . . . . 57

5.3 .1 Bidens subalternans . . . . . . . . . . . . . . 59

5.3 .2 Bidens pilosa....................... 62

5.3 .3 Discussão . . . . . . . . . . . . . . . . . . . . 67

6 Conclusões $\quad 69$

6.1 Propostas para trabalhos futuros . . . . . . . . . . . . . . . 69

$\begin{array}{ll}\text { Referências Bibliográficas } & 71\end{array}$ 


\section{Lista de Figuras}

FIGURA 5.1 Curvas de dose-resposta dos herbicidas atrazine e nicosulfuron utilizando os parâmetros encontrados na Tabela 5.2 e seus respectivos parâmetros $G R_{80}$ de cada curva. . . . . . . . . . . . . . . . 51

FIGURA 5.2 Comportamento genético populacional da Bidens subalternans sob o efeito do herbicida atrazine. (a) Frequência do gene resistente, (b) Frequência de indivíduos resistentes, (c) Tamanho do banco de sementes e (d) Eficácia da dose. . . . . . . . . . . . . . . . . . . 51

FIGURA 5.3 Comportamento genético populacional da Bidens subalternans sob o efeito do herbicida nicosulfuron. (a) Frequência do gene resistente, (b) Frequência de indivíduos resistentes, (c) Tamanho do banco de sementes e (d) Eficácia da dose. . . . . . . . . . . . . . . 5

FIGURA 5.4 Simulação do MSBSB da Bidens subalternans sob o efeito do herbicida nicosulfuron. (a) Frequência de indivíduos resistentes e (b) Tamanho do banco de sementes. . . . . . . . . . . . . . 53

FIGURA 5.5 Simulação do MCGP da Bidens subalternans sob o efeito do herbicida nicosulfuron. (a) Frequência de indivíduos resistentes (b) Razão entre os genótipos e (c) Frequência do gene de resistência. . . . . . . . . 53

FIGURA 5.6 Curvas de dose-resposta dos herbicidas chlorimuron-ethyl e imazetaphyr utilizando os parâmetros encontrados na Tabela 5.3 e seus respectivos parâmetros $G R_{80}$ de cada curva. . . . . . . . . . . . . 54 
FIGURA 5.7 Comportamento genético populacional da Bidens pilosa sob o efeito do herbicida chlorimuron-ethyl. (a) Frequência do gene resistente, (b) Frequência de indivíduos resistentes, (c) Tamanho do banco de sementes e (d) Eficácia da dose. . . . . . . . . . . . . . . . . .

FIGURA 5.8 Comportamento genético populacional da Bidens pilosa sob o efeito do herbicida imazetaphyr. (a) Frequência do gene resistente, (b) Frequência de indivíduos resistentes, (c) Tamanho do banco de sementes e (d) Eficácia da dose. . . . . . . . . . . . . . . . . . . . 55

FIGURA 5.9 Simulação do MSBSB da Bidens pilosa sob o efeito do herbicida chlorimuron-ethyl. (a) Frequência de indivíduos resistentes e (b) Tamanho do banco de sementes. . . . . . . . . . . . . . 56

FIGURA 5.10 Simulação do MCGP da Bidens pilosa sob o efeito do herbicida chlorimuron-ethyl. (a) Frequência de indivíduos resistentes (b) Razão entre os genótipos e (c) Frequência do gene de resistência. . . . . . . . . 56

FIGURA 5.11 Função $v(x, p)-p$ na região dos pontos de equilíbrio, com (a) $x=111$ e (b) $x=312$ para herbicida atrazine. . . . . . . . . . . 60

FIGURA 5.12 Função $f(x, p)-x$ na região dos pontos de equilíbrio, com (a) $p=1$ e (b) $p=0$ para herbicida atrazine. . . . . . . . . . . 60

FIGURA 5.13 Plano de fase do modelo com uso do herbicida atrazine na dose

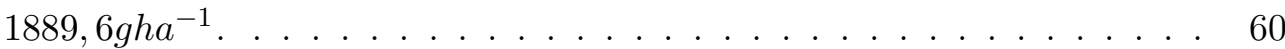

FIGURA 5.14 Função $v(x, p)-p$ na região dos pontos de equilíbrio, com (a) $x=66$ e (b) $x=463$ para o herbicida nicosulfuron. . . . . . . . .

FIGURA 5.15 Função $f(x, p)-x$ na região dos pontos de equilíbrio, com (a) $p=1$ e (b) $p=0$ para o herbicida nicosulfuron. . . . . . . . . . .

FIGURA 5.16 Plano de fase do modelo com uso do herbicida nicosulfuron na dose $51,725 g h a^{-1} \ldots \ldots \ldots \ldots \ldots \ldots$

FIGURA 5.17 Função $v(x, p)-p$ na região dos pontos de equilíbrio, com (a) $x=16$ e (b) $x=1057$ para o herbicida chlorimuron-ethyl. . . . . . . .

FIGURA 5.18 Função $f(x, p)-x$ na região dos pontos de equilíbrio, com (a) $p=1$ e (b) $p=0$ para o herbicida chlorimuron-ethyl. . . . . . . . . 
FIGURA 5.19 Plano de fase do modelo com uso do herbicida chlorimuronethyl na dose $13,3 g h a^{-1} \ldots \ldots \ldots \ldots$

FIGURA 5.20 (a) Função $v(x, p)-p$ na região dos pontos de equilíbrio, com $x=50$. (b) Função $f(x, p)-x$ na região dos pontos de equilíbrio, com $p=1$ para o herbicida imazetaphyr na dose $41,3 g h a^{-1} \ldots \ldots$. . . . . 64

FIGURA 5.21 Plano de fase do modelo com uso do herbicida imazetaphyr na

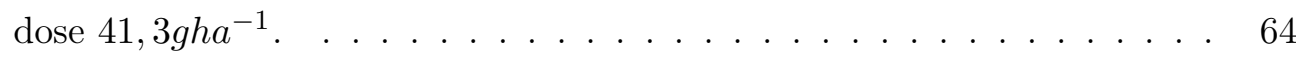

FIGURA 5.22 Função $v(x, p)-p$ na região dos pontos de equilíbrio, com (a) $x=84$ e (b) $x=389$ para o herbicida imazetaphyr na dose $20 g h a^{-1} .$.

FIGURA 5.23 Função $f(x, p)-x$ na região dos pontos de equilíbrio, com (a) $p=1$ e (b) $p=0$ para o herbicida imazetaphyr na dose $20 g h a^{-1} \ldots$. .

FIGURA 5.24 Plano de fase do modelo com uso do herbicida imazetaphyr na

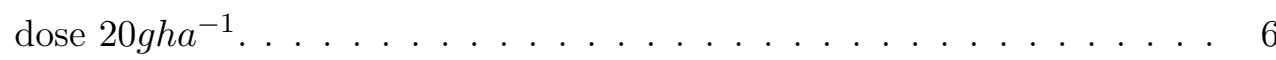

FIGURA 5.25 Função $v(x, p)-p$ na região dos pontos de equilíbrio, com (a) $x=52$ e (b) $x=545$ para o herbicida imazetaphyr na dose $15 g h a^{-1} \ldots 66$

FIGURA 5.26 Função $f(x, p)-x$ na região dos pontos de equilíbrio, com (a) $p=1$ e (b) $p=0$ para o herbicida imazetaphyr na dose $15 g h a^{-1} \ldots$. . . 66

FIGURA 5.27 Plano de fase do modelo com uso do herbicida imazetaphyr na

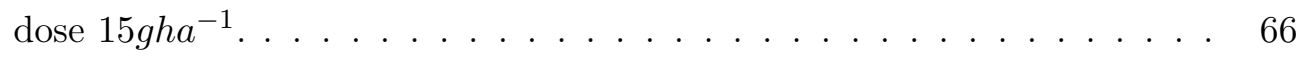




\section{Lista de Tabelas}

TABELA 3.1 Definição dos parâmetros e variáveis do modelo de Maxwell . . 24

TABELA 3.2 Definição dos parâmetros e variáveis do modelo de Maxwell

(Cont.) . . . . . . . . . . . . . . . . 25

TABELA 3.3 Definição dos parâmetros e variáveis do modelo de Diggle . . 28

TABELA 4.1 Definição dos parâmetros e variáveis do submodelo de recombinação genética . . . . . . . . . . . . . . . . . . . . . . . 39

TABELA 4.2 Definição dos parâmetros e variáveis do submodelo populacional 42

TABELA 5.1 Valores dos parâmetros do submodelo populacional utilizados nas simulações . . . . . . . . . . . . . . . . . . 5 50

TABELA 5.2 Parâmetros de dose-resposta da planta Bidens subalternans resistente e suscetível aos herbicidas atrazine e nicosulfuron . . . . . . . 50

TABELA 5.3 Parâmetros no modelo log-logístico de dose resposta da planta Bidens pilosa resistente e suscetível aos herbicidas chlorimuron-ethyl e imazetaphyr . . . . . . . . . . . . . . . . . . . 54

TABELA 5.4 Pontos de equilíbrio do modelo dinâmico para a Bidens subal-

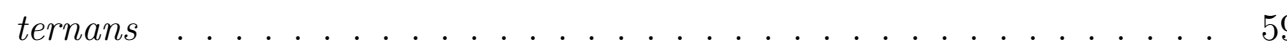

TABELA 5.5 Pontos de equilíbrio do modelo dinâmico para Bidens pilosa . 62 


\section{Resumo}

Este trabalho propõe um modelo dinâmico para análise de populações de plantas daninhas resistentes a herbicidas. O modelo representa a dinâmica populacional causada por um aumento na proporção de plantas resistentes a herbicidas, resultante da recombinação genética modificada pela pressão seletiva causada pelo herbicida. O aumento da resistência causa uma diminuição na eficácia da dose aplicada do herbicida sobre toda população e, eventualmente, compromete o controle desta população. São apresentados resultados de simulação da planta daninha Bidens subalternans, resistente ao herbicida nicosulfuron e tolerante ao herbicida atrazine, e da planta daninha Bidens pilosa, resistente ao herbicida chlorimuron-ethyl e tolerante ao herbicida imazetaphyr para diferentes doses de herbicidas.

Palavras-chave: Resistência de plantas daninhas; herbicida; controle de planta daninha; modelos não lineares; dose-resposta; Bidens subalternans; Bidens pilosa. 


\section{Abstract}

This paper proposes a dynamic model for analysis of herbicide resistance in weed populations. The model represents population dynamic caused by an increase in the proportion of plants resistant to herbicides, resulting from genetic recombination modified by selective pressure caused by herbicide. The increase of resistance decreases the efficacy of the applied dose of herbicide over the entire population and, eventually compromises the population control. Results of simulation for different doses are presented for the weed Bidens subalternans, resistant to nicosulfuron and tolerant to atrazine, and for the weed Bidens pilosa, resistant to herbicide chlorimuron-ethyl and tolerant to imazetaphyr.

Keywords: Weed resistence; herbicide; weed control; non linear models; doseresponse; Bidens subalternans; Bidens pilosa. 


\section{Capítulo 1}

\section{Introdução}

O controle de uma população de plantas daninhas em culturas agrícolas tem sido realizado principalmente pelo uso de herbicidas. Este método de controle tem como vantagens menor custo e grande eficácia. Porém, estão surgindo mais espécies de plantas daninhas com resistência confirmada aos herbicidas (WeedScience 2009).

As doses de herbicidas são fixadas para garantir um grau de controle eficaz sob diversas condições ambientais e de manejo (Rizzardi e Fleck 2004). Se o uso de doses abaixo da recomendada pode causar o aumento de casos de resistência ainda está em estudo segundo Christoffoleti (2008). Porém, é conhecido que o uso intensivo de herbicidas é uma causa para o aumento da resistência em populações de plantas daninhas (Gressel 2009).

A grande eficácia encontrada nos produtos químicos utilizados para o controle de plantas daninhas gera uma seleção de determinadas espécies de plantas daninhas que são mais tolerantes aos herbicidas utilizados. A aplicação repetitiva de um ou mais herbicidas, com o mesmo mecanismo de ação, em uma população de plantas daninhas, seleciona os indivíduos com a habilidade de sobreviver aos tratamentos desses herbicidas (Dias 2004).

De acordo com Diggle et al. (2003), a probabilidade de aparecimento da resistência e sua taxa de crescimento dentro da população depende da interação entre a dinâmica populacional e as características genéticas das plantas daninhas. Torna-se necessário estudar os fatores evolucionários envolvidos a fim de compreender melhor a resistência a herbicidas de determinadas populações. Alguns fatores evolucionários importantes são: 
a intensidade de seleção (grau de discriminação entre os biótipos, ou seja, a diferença entre os biótipos presentes na população); a frequência do traço de resistência em populações naturais (seleção natural); o modelo de herança da resistência; o fitness relativo a biótipos suscetíveis e resistentes na presença e ausência de herbicida; e a troca genética entre populações.

A seleção natural é amplamente aceita como explicação para o desenvolvimento da resistência a condições ambientais adversas (Wright 1972). Sendo assim, biótipos resistentes a herbicidas normalmente existem em baixa frequência numa espécie de planta daninha. Em alguns casos um único membro é resistente (uma característica criada através de uma mutação genética). Quando o herbicida é aplicado, o mesmo atua como agente de pressão de seleção, matando as plantas suscetíveis enquanto as plantas resistentes sobrevivem e se reproduzem.

O biótipo resistente não infestará totalmente uma área analisada em pouco tempo. A resistência na população é identificada, geralmente, quando mais de $30 \%$ das plantas mostram-se resistentes (Christoffoleti 2008). Nesse momento a resistência já se apresenta na forma de pequenas áreas dominadas por somente plantas daninhas resistentes no campo (reboleiras). As primeiras reboleiras normalmente sofrem controle mecânico (capina), mas o gene que gera a resistência já está fixado na população e o controle através somente de herbicida já não irá apresentar a mesma eficácia de quando a população era composta somente do biótipo suscetível ao herbicida.

Com a aplicação repetitiva do herbicida com o mesmo mecanismo de ação ocorre um aumento da proporção do biótipo resistente na população e, finalmente, há o domínio deste biótipo na população que habita a área analisada. A extensão de áreas agrícolas atualmente detectadas com presença de biótipos resistentes de plantas daninhas pode ser considerada de pequena escala quando comparada com a área agrícola total mundial, porém está ocorrendo um aumento da quantidade de áreas com novos casos de resistência detectados (WeedScience 2009).

Os primeiros casos de evolução de resistência conhecidos envolveram mudanças no local de ação dos herbicidas, ou seja, o biótipo resistente possui uma diferenciação no local onde o herbicida age, do mesmo modo como ocorreram os primeiros casos de evolução de resistência a inseticidas e fungicidas (Harper 1956). Do ponto de vista evolucionário, a resistência a herbicidas, se for contado em gerações e não em anos, ocorreu na mesma 
velocidade que a resistência a inseticidas e fungicidas. Porém, do ponto de vista do agricultor, as resistências a fungicidas e inseticidas ocorreram primeiramente, uma vez que estas pragas possuem diversas gerações em um único ano.

Devido ao tempo necessário para observar o aumento da resistência de plantas daninhas a herbicidas, o uso de modelos matemáticos que expressem a dinâmica da população de plantas daninhas pode ser útil. Assim, podem ser observados e previstos vários cenários possíveis para a população de plantas daninhas.

Um dos modelos normalmente utilizados para entender a dinâmica entre plantas e o herbicida usado para controlá-las é a curva de dose-resposta. Para obter uma curva de dose-resposta existem diversos métodos, porém, o mais utilizado, segundo Christoffoleti (2008), é o modelo matemático log-logístico proposto por Seefeldt et al. (1995). O modelo log-logístico apresenta inúmeras vantagens em relação a outros métodos de análise. A principal característica desse modelo é que um dos seus parâmetros, o parâmetro $G R_{50}$, que é a dose de herbicida necessária para controlar $50 \%$ da população, facilita a comparação do nível de resistência dos biótipos testados.

Diversos autores têm utilizado e recomendado curvas de dose-resposta para determinar a suscetibilidade ou resistência de plantas daninhas aos herbicidas aplicados em diversas culturas (Streibig e Kudsk 1993, Lacerda e Victoria Filho 2004, Kim et al. 2006, Haage et al. 2007, Smith et al. 2008, Merotto et al. 2009).

A curva de dose-resposta fornece informação sobre o estado atual da resistência a herbicidas da variedade de planta analisada, definindo como uma população formada por esta variedade irá responder ao controle através de determinada dose de herbicida. Já para definir alterações de tamanho dessa população analisada é necessário o uso de um modelo populacional. Diversos autores (Gressel e Segel 1978, B. D. Maxwell 1990, Diggle et al. 2003, Neve et al. 2003) propuseram modelos descrevendo a dinâmica de uma população de plantas com resistência a herbicidas, porém, sem o estudo do efeito de diferentes doses de herbicida.

\subsection{Objetivos}

O objetivo deste trabalho foi desenvolver um modelo para prever o estado da resistência das plantas daninhas a herbicidas ao longo de seus diversos ciclos durante sua 
vida. Baseado principalmente nos modelos de Cacho (1999), Seefeldt et al. (1995) e Britton (2003), esse modelo pode ser utilizado no planejamento do controle da infestação de plantas daninhas, com o uso de doses de herbicida reduzidas e, portanto, diminuindo custos em um determinado período de tempo. Foram realizadas simplificações no ciclo de vida da planta e a não segregação entre biótipos. A análise da dinâmica populacional do modelo servirá como uma ferramenta para a compreensão do atual e futuro estado da resistência de algumas espécies de plantas daninhas que afetam a cultura de milho e sorgo.

\subsection{Organização do trabalho}

O trabalho encontra-se dividido em capítulos. No Capítulo 1, são apresentadas as motivações e justificativas do trabalho. No Capítulo 2 são apresentados conceitos utilizados para controle de infestações de plantas daninhas, o que é a resistência a herbicidas e como essa resistência é detectada. No Capítulo 3 são apresentados os principais modelos encontrados na literatura, qual a contribuição de cada um, como esses modelos foram desenvolvidos e as características relevantes comuns aos modelos. No Capítulo 4 é apresentado o desenvolvimento do modelo proposto a partir dos modelos encontrados na literatura, a estrutura do modelo, justificativas e também a proposta do modelo utilizando múltiplos herbicidas. No Capítulo 5 são realizadas diversas simulações para obter a dinâmica esperada de aumento da resistência a herbicidas. É feita uma análise do comportamento populacional. Também é realizada uma análise dos pontos de equilíbrio do modelo proposto. No Capítulo 6 são apresentadas as conclusões do trabalho e propostas para possíveis futuros trabalhos. 


\section{Capítulo 2}

\section{Revisão bibliográfica}

\section{$2.1 \quad$ Plantas daninhas}

As plantas daninhas, por definição, são plantas que crescem espontaneamente em solo utilizado para cultivo e têm um comportamento que compromete a qualidade do cultivo (Jones e Cacho 2000). Existem espécies que são nativas da área, porém, pode haver presença de espécies imigrantes, trazidas por diversos meios, inclusive junto ao lote de sementes para cultivo, devido ao beneficiamento fora das normas estabelecidas de qualidade e pureza das sementes para cultivo.

A grande variabilidade genética encontrada nas plantas daninhas é uma característica importante para compreender a resistência a herbicidas. Os fatores que geram a variabilidade genética são: a presença em diferentes regiões e, portanto, adaptabilidade aos mais diversos climas e solos; o fato de possuírem diversos métodos de reprodução; facilidade e rapidez de reprodução; o estabelecimento de um banco de sementes dormentes e a capacidade de manter múltiplas gerações protegidas de condições não favoráveis durante períodos prolongados.

Plantas daninhas têm como principal vantagem sobre a planta cultivada a sua adaptabilidade: por serem capazes de se adaptar a qualquer local ou condições climáticas não necessitam dos mesmos cuidados que a planta cultivada exige. Com o tempo, a população de plantas daninhas cresce, devido à sua rápida reprodução, infestando a área. Passa a acontecer uma competição por recursos entre a cultura e a infestação de plantas daninhas que prejudica o rendimento econômico da cultura. 


\subsubsection{Banco de sementes}

O banco de sementes é um conjunto de sementes presentes no solo que germinam conforme este banco é estimulado por condições externas, por causa disto, não há uma geração homogênea entre as plantas germinadas desse banco de sementes, podendo haver plantas germinadas de sementes geradas em diferentes épocas.

A existência de um banco de sementes torna o controle de plantas daninhas diferenciado do controle de outras pragas. O banco de sementes normalmente não é afetado pelo controle por herbicida. Algumas técnicas são capazes de modificar a dinâmica do banco de sementes: no plantio direto, no qual não há tratamento do solo entre a colheita e o novo plantio, o banco de sementes se torna pouco ativo, pois somente as novas sementes se desenvolvem, já que se mantêm na superfície, tendo maior acesso à água, luz e nutrientes; no plantio com aração do solo torna essa dinâmica diferente, pois mistura novas sementes com as já presentes no banco; na cobertura do solo, que por sua vez, aumenta a camada de solo (pela adição de palhada sobre o solo) assim dificultando a germinação das sementes do banco.

Vários modelos apresentados (Jones e Cacho 2000, B. D. Maxwell 1990, Diggle et al. 2003) descrevem o banco de sementes como um delay ou buffer genético, atrasando a evolução da resistência ao não expor todos os indivíduos aos fatores de pressão seletiva de uma vez. Também resguarda possíveis indivíduos resistentes de serem detectados, dificultando a análise sobre o atual estado da resistência da população. Uma análise da resistência a herbicidas deve contemplar o banco de sementes e não somente plantas emergidas.

\subsubsection{Mecanismos de reprodução}

As plantas, de modo geral, possuem diferentes mecanismos usados na sua reprodução. Estas são capazes de se reproduzir tanto sexuadamente como assexuadamente, através de sementes ou frutos, possuem também mecanismos como autofecundação e clonagem. São também capazes de se reproduzir mais de uma vez durante seu ciclo de vida não sendo possível distinguir completamente suas gerações.

Cada diferente mecanismo de reprodução utilizado pela planta resulta em uma diferente dinâmica de recombinação genética. Os modelos estudados que representam esta 
dinâmica tendem a usar equações que reforçam o fato de plantas poderem se reproduzir com indivíduos muito próximos e realizarem autofecundação (B. D. Maxwell 1990). Diggle et al. (2003) afirmam que reprodução de plantas não é um processo totalmente aleatório, pois a área de alcance do fluxo de pólen e do espalhamento de sementes é restrita, limitando a quantidade de parceiros para a reprodução.

O modo como os genes são recombinados durante a reprodução para gerar características que tornam a planta resistente ao herbicida também é variada. Pouco pode ser dito sobre cada planta sem investigar detalhadamente o genoma da planta. Porém, os casos mais comumente observados são os de alelos dominantes ou alelos recessivos.

No caso dominante, um único alelo responsável pela resistência presente no locus (ou seja, há apenas a necessidade de um dos pais ser resistente) é necessário para que haja a expressão do biótipo resistente no indivíduo. No caso recessivo, há a necessidade de dois destes alelos (ambos os pais resistentes) no locus para que estes combinados expressem um biótipo resistente. Há outros casos conhecidos, como a semi-dominância e a poligenia, na maioria destes e de outros casos pode ser feita uma simplificação, encaixando em um caso dominante ou recessivo.

\subsection{Métodos de controle da população de plantas daninhas}

O controle de populações de plantas daninhas e outras pragas se tornou essencial para o atual nível de produtividade agrícola mundial. O controle em si é mais um custo ao produtor, mas que se reflete em um lucro maior que no caso deste controle não ter sido realizado. Diversos métodos de controle de populações de planta daninha são utilizados atualmente, normalmente em conjunto para se complementarem. Esses métodos são basicamente divididos em três grupos: o controle mecânico, o controle químico e o controle cultural. Novos métodos de manejo estão sendo propostos atualmente (Gressel 2009, Gressel 2011) incluindo novos métodos de controle biológico, desenvolvidos a partir das pesquisas com o glifosato e plantas geneticamente modificadas.

O controle mecânico e o cultural incluem técnicas de manejo do solo, da cultura e das plantas daninhas. Alguns exemplos são o tratamento e preparação correta do solo que procuram inviabilizar as sementes de plantas daninhas presentes no banco de sementes. A cultura sendo plantada corretamente, além de torná-la mais viável, pode 
evitar os períodos de aparecimento das plantas daninhas infestantes. A capina manual retira as plantas daninhas.

O controle químico é realizado com o uso de herbicidas. Desde o início, o desenvolvimento de herbicidas acompanha o de outros agentes químicos e farmacológicos, havendo constante desenvolvimento de novos herbicidas para controle de novas e antigas plantas daninhas.

A compreensão do modo de ação do herbicida depende do entendimento da bioquímica presente nos processos fisiológicos da planta. O modo de ação afeta um ou mais mecanismos essenciais para o desenvolvimento ou mesmo para a sobrevivência da planta.

O processo de aplicação de herbicida para o controle de plantas daninhas gera custos significativos ao produtor. Ao longo dos anos, foram desenvolvidos diversos herbicidas seletivos e eficazes para o uso em culturas, possibilitando mudar de uma solução basicamente preventiva para uma reparadora no controle de plantas daninhas (Rizzardi e Fleck 2004).

O aumento da seletividade do herbicida visa reduzir o dano causado à cultura, afetando somente plantas daninhas, evitando assim qualquer prejuízo causado pela aplicação do herbicida sobre a cultura que deve se manter saudável a fim de obter um índice de produtividade aceitável. A seletividade procura aumentar a eficácia econômica na cultura, já que o herbicida pode ser usado em doses baixas ou altas sem que haja prejuízos. Porém, uma maior seletividade pode causar um aumento acelerado da resistência (May e Dobson 1986). A causa deste possível comportamento deve-se a um herbicida seletivo afetar apenas um mecanismo vital da planta daninha através de um modo de ação muito específico e, se a planta por algum motivo for capaz de alterar o local dessa ação, será resistente a este herbicida.

O modo de ação dos herbicidas pode ser dividido em grupos, de acordo com o seu local de ação e família química (Menne 2005). Os processos utilizados para a mortandade de plantas daninhas são conhecidos e documentados durante seu desenvolvimento. Normalmente, é primeiramente descoberto um mecanismo específico de certo grupo de plantas daninhas e que são diferentes (inexistentes, diferenciados ou em proporção diferente) nas plantas cultivadas, então, são desenvolvidos princípios ativos capazes de impedir o correto funcionamento dos mecanismos das plantas daninhas, evitando afetar 
as plantas cultivadas. Devido à existência de diversos fabricantes de herbicidas, existem muitos produtos comerciais com o mesmo modo de ação, mesmo não tendo exatamente o mesmo princípio ativo, um infográfico completo pode ser encontrado em HRAC (2000).

A eficácia da dose aplicada se relacionada com o problema de resistência. Quanto maior a eficácia, mais rapidamente os indivíduos resistentes serão a maioria na população (mesmo a população sendo reduzida), já que os indivíduos resistentes não são afetados pela dose de herbicida.

Fatores ambientais, principalmente o clima, mudam radicalmente a eficácia da dose das mais diversas formas. Como exemplos, chuvas podem tornar a aplicação menos eficiente, clima seco e quente pode afetar a absorção do herbicida, umidade do solo afeta seriamente herbicidas aplicados no solo e diversas outras possibilidades podem ocorrer e afetar a eficácia da dose em campo. A forma de medir esta eficácia é através da relação entre dose e resposta presente no modelo de Seefeldt et al. (1995) normalmente obtida através de experimentos, em estufas isoladas, retirando qualquer fator externo que possa causar alterações.

\subsection{Resistência como característica genética de plantas da- ninhas}

A resistência de uma espécie de planta daninha a um herbicida é a capacidade adquirida e herdável de alguns biótipos da mesma espécie de sobreviverem e se reproduzirem após a exposição à dose de um herbicida (Christoffoleti 2008). A utilização de herbicidas com residual prolongado ou herbicidas sem ação residual aplicados repetidamente, o uso de herbicidas com alto grau de eficácia e a aplicação de doses elevadas proporcionam uma pressão seletiva muito grande, favorecendo o desenvolvimento do biótipo resistente (Christoffoleti et al. 1994, Vidal e Fleck 1997).

O desenvolvimento da resistência a herbicidas numa população de plantas daninhas é resultado de um fenômeno evolucionário (Friedman e Diggle 2011). Os herbicidas aplicados são fortes agentes de seleção e, onde a variabilidade genética é grande, são capazes de pressionar toda esta variabilidade para apenas um biótipo, favorecendo indivíduos que possuem características que os tornam resistentes aos herbicidas. 
A resistência a herbicidas é apenas mais um passo na evolução das plantas. Porém, a resistência a herbicidas é causada por características dificilmente observáveis. Isto ocorre devido ao modo de ação do herbicida, que ocorre na fisiologia interna, dentro de algum processo bioquímico da planta. As diferenças que tornam as plantas resistentes estão presentes em pequenas alterações nessa fisiologia, algo que não pode ser observado sem uma profunda análise laboratorial. A alteração faz com que o princípio ativo do herbicida não consiga agir como deveria, tornando-o ineficaz. Essas alterações fisiológicas são causadas por pequenas diferenças no material genético entre as plantas resistentes e suscetíveis. Poucos estudos existem sobre os processos de resistência e como são causados por alterações genéticas na planta (Duke e Gressel 2010).

O fato de não observar esta resistência torna sua deteç̧ão mais difícil, métodos de deteç̧ão e confirmação da resistência têm sido desenvolvidos e utilizados largamente. Muito material científico sobre novos casos está sendo disponibilizado, assim como casos de resistência a herbicidas têm se multiplicado ao redor do mundo (WeedScience 2009).

Atualmente compreende-se melhor o cenário enfrentado, segundo conclusões de Neve (2008), plantas controladas com métodos de manejo tradicionais e doses comerciais de herbicida apresentam resistência detectável somente após longos ciclos da cultura. Harper (1956) previu o aparecimento de plantas resistentes juntamente com o aparecimento de resistência aos demais agentes químicos que começaram a ser utilizados na época. Portanto, o problema de resistência é estudado há muitos anos e o cenário esperado tenderá a piorar nos próximos anos (Gressel 2009, Gressel 2011). Outros modelos da literatura (Diggle et al. 2003, Neve et al. 2003) que preveem o aumento da resistência a herbicidas levam às mesmas conclusões.

A planta normalmente é resistente a apenas um princípio ativo, porém, pode ocorrer a resistência a mais membros da mesma família química do herbicida que possuem o mesmo modo de ação, resultando em resistência cruzada. Algumas plantas apresentam resistência a herbicidas que não pertencem à mesma família química e não têm nenhuma ligação no seu modo de ação, neste caso, ocorre então resistência múltipla onde a planta provavelmente possui dupla resistência, uma para cada um desses herbicidas.

Casos de resistência cruzada são mais comuns com o uso constante de herbicidas do mesmo modo de ação. Esta prática é comum e pode levar o mecanismo de resistência da planta a ser efetivo para não somente um ou outro herbicida, mas para toda a família 
química a qual o herbicida pertence.

Casos de resistência múltipla são mais difíceis de detectar e as alternativas para controle químico de uma população com este tipo de resistência são reduzidas (pois existe resistência ao herbicida normalmente utilizado e a outro, normalmente o que é utilizado como alternativa), casos como este estão documentados em WeedScience (2009).

\subsubsection{Características que levam à resistência de toda uma população}

É observado que a resistência tem origens genéticas, resultante de uma longa evolução natural, causada por uma inicial mutação em um indivíduo desconhecido, favorecendo sua sobrevivência e reprodução. Essa mutação é então passada para seus descendentes.

Há dois precursores da evolução de uma resistência: a ocorrência de variações hereditárias e seleção natural. A mutação ou ocorrência de variações hereditárias é resultado de erros durante a recombinação dos genes, seja durante a reprodução ou durante o crescimento da planta, normalmente só é observado mutações somente se são benéficas, pois somente assim um único indivíduo que sofreu mutação não será extinto e conseguirá passar essa mutação à próxima geração. A seleção natural torna indivíduos mais aptos cada vez mais presentes na população. De modo geral, dada a existência de variação genética e o uso recorrente de herbicida, há seleção direcionada, havendo uma progressiva adaptação da população.

As ocorrências de mutações acontecem de forma aleatória, mas o que as tornam sucessos evolucionários é o como o ambiente age sobre diferente tipos de indivíduos (biótipos), eliminando os que não possuam características favoráveis no ambiente. As condições ambientais impostas são fatores de degradação, como condições naturais ou artificiais, mudanças climáticas bruscas, toxidade ambiental, falta de nutrientes, doenças, agentes químicos, poluição, entre outros (Britton 2003).

Geneticamente, existem duas formas da resistência tornar-se um fenótipo. Um alelo responsável (ou alelos) pode ocorrer em uma frequência muito baixa na população, ou pode ocorrer uma mutação, de modo que a seleção atua para mudar o que é uma população suscetível (por exemplo, predominantemente genótipo aa para AA resistente). Alternativamente, essa seleção pode atuar sobre uma variação contínua (poligenia) e 
conseguir um aumento na resistência média de geração em geração com mudanças na frequência gênica, até que muitos loci estejam ativos, conferindo à planta resistência poligênica.

O aumento da presença do gene de resistência na população ocorrerá mais rapidamente em populações que este gene já está presente, mesmo em baixíssima frequência. O que determina a velocidade da evolução é a força seletora que mata os indivíduos não preparados e que não causa grandes efeitos sobre os que possuem em seu DNA o gene de resistência.

Este processo é evolutivo e dinâmico: diferenças na pressão seletiva alteram a velocidade da disseminação da característica na população, diferentes forças seletoras levam à evolução a diferentes direções evolutivas. A direção evolutiva estudada será somente uma: a resistência ao herbicida. Diferenças na dose do herbicida causam uma diferença na velocidade da evolução da resistência. Essa dinâmica de evolução pode ser entendida como uma função da chamada pressão seletiva.

Pressão seletiva é definida como o resultado de diversos forças seletoras que dão a um determinado biótipo uma vantagem de sobrevivência e reprodutividade em relação aos demais. A mais notável força seletora é a pressão seletiva gerada pelo herbicida e sua resistência presente num biótipo da planta. Sabe-se que a dose do herbicida varia proporcionalmente à pressão seletiva gerada.

Outros fatores agem em conjunto ou independentemente do herbicida. A maioria desses outros fatores não são mensuráveis, suas influências normalmente são sutis ou são, na maioria dos casos, homogêneos a toda população, ou seja, todos são afetados, nenhum indivíduo é favorecido por uma força seletora. Mas, mesmo nesses casos alguns se saem melhor que os demais, mesmo que por uma pequena diferença, então ainda assim está caracterizado uma pressão seletiva.

A vantagem evolutiva também conhecida como fitness é o diferencial que existe naqueles indivíduos que são capazes de resistir à pressão seletiva. Enquanto a pressão seletiva seleciona os indivíduos, o fitness é a característica que faz estes indivíduos serem selecionados. O fitness também é importante para o controle de plantas resistentes. Existem casos conhecidos em que o biótipo suscetível tem um fitness maior que o biótipo resistente (Christoffoleti 2008), nestes casos a ausência de controle através de herbicida favorece a queda do índice de resistência na população de plantas dani- 
nhas. Alguns modelos (May e Dobson 1986) utilizam desta possibilidade (maior fitness do biótipo suscetível sem o controle através de herbicida) para chegar ao controle do biótipo resistente.

\subsection{Metodologia de detecção de possíveis casos de resistên- cia}

A obtenção da curva de dose-resposta de variedades diferentes de plantas é a parte essencial de um dos métodos mais utilizados para detecção de plantas resistentes. A seguir será apresentado um método que utiliza análise das curvas de dose-resposta para detectar casos de resistência.

Primeiramente, é importante definir os indivíduos candidatos. A observação atenta de um especialista é capaz de distinguir, dentro de uma população, aquelas plantas com características resistentes. Porém, estes sinais podem ser resultado de outros fatores como: má distribuição do herbicida, chuva, germinação subsequente, condições de solo, temperatura e condições de luminosidade. Todos esses fatores podem fazer com que certos indivíduos sobrevivam enquanto os demais pereçam. Um indivíduo saudável próximo a indivíduos já mortos numa população afetada por um herbicida é um grande suspeito de pertencer ao biótipo resistente.

A planta suspeita deve ter suas sementes recolhidas, com objetivo de analisar a resposta ao herbicida das descendentes que nascerem destas sementes. Portanto, essas sementes devem ser minimamente afetadas por quaisquer outras condições, para que não haja prejuízo nos resultados. Normalmente, não são utilizadas as primeiras sementes, mas suas descendentes, com o objetivo de aumentar a amostragem. Com uma população de descendentes daquele indivíduo suspeito de resistência, é possível fazer análise da resposta da planta ao herbicida. Isto pode ser feito de dois modos: ensaios de dose única ou experimento de dose-resposta.

Ensaios de dose única normalmente testam a dose equivalente à $G R_{50}$ (dose que causa $50 \%$ da eficácia na resposta) ou a dose recomendada de uso agrícola $\left(G R_{80}\right.$, dose que causa $80 \%$ ). Então é analisada a resposta da planta suspeita e comparada com o controle (planta suscetível). Respostas ineficientes a doses comuns são esperadas em plantas resistentes. Porém este tipo de ensaio não é suficiente para determinar se a 
planta é de um biótipo resistente, para isto é necessário um ensaio de dose-resposta.

O modo mais completo é o experimento de dose-resposta, onde é feita a análise de todo espectro de respostas às mais diferentes doses de herbicidas, assim podem ser analisadas doses inferiores e superiores às normalmente utilizadas em campo. Com essa análise, pode-se usar o índice de resistência $\left(I_{r}\right)$, que é a divisão da dose $G R_{50 R}$ da planta resistente pela $G R_{50 S}$ da planta suscetível (Moss 1999):

$$
I_{r}=\frac{G R_{50 R}}{G R_{50 S}}
$$

Este índice é utilizado na definição científica de resistência, pois implica uma diferença suficiente para segregação da população em um biótipo suscetível e um resistente. Porém, segundo Christoffoleti (2008), o indivíduo resistente por definição agronômica deve sobreviver à dose recomendada sobre condições normais de campo, o que não pode ser verificado apenas por este índice. Normalmente, opta-se pela definição agronômica de resistência, em que a planta só será resistente se não for afetada por uma dose muito superior à normalmente utilizada e qualquer alteração na eficácia da dose no nível $G R_{50}$ é considerado tolerância. Um caso de tolerância pode ser entendido como um individuo capaz de sobreviver a doses de herbicida abaixo das normalmente aplicadas, mas não à dose recomendada $G R_{80}$.

\subsubsection{Função dose-resposta}

A relação entre a dose de herbicida e a resposta da planta é de fundamental importância para a compreensão da eficácia do herbicida e seu modo de ação. A função de dose-resposta tem como objetivo quantificar a sensibilidade da planta ao herbicida. Mudanças nessa sensibilidade alteram a função. Plantas resistentes têm uma menor sensibilidade ao herbicida, portanto sua função dose-resposta difere da função dose-resposta da planta suscetível da mesma espécie. Essa diferença na função dose-resposta é usada para detectar casos de resistência a herbicidas (Moss 1999). A função de dose-resposta é dada pelo modelo log-logístico com quatro parâmetros:

$$
\rho(u)=c+\frac{d-c}{1+\exp \left[b\left(\log (u)-\log \left(G R_{50}\right)\right)\right]},
$$


em que $c$ é o limite inferior da curva, $d$ é o limite superior da curva, $b$ é a declividade da curva em torno de $G R_{50}, G R_{50}$ corresponde à dose necessária para reduzir $50 \%$ do crescimento da planta daninha em relação à testemunha (Seefeldt et al. 1995).

Os parâmetros de 2.2 sofrem pequenas alterações em cada planta, por pequenas diferenças fisiológicas no desenvolvimento de cada uma. Dentre as principais diferenças fisiológicas que alteram a resposta da planta está a resistência da planta ao herbicida aplicado. Esta dispersão esperada das medições dentro dos experimentos que definem os parâmetros do modelo de dose-resposta exige que múltiplas repetições sejam realizadas sobre um grande número de amostras a fim de se obter uma curva de dose-resposta que corresponda a uma média da população.

Podem ser analisadas diferentes respostas à dose de herbicida. A resposta normalmente analisada é a perda de biomassa ou o índice de massa verde. Estes resultados são utilizados para observar a eficácia com que se pode retardar o crescimento da planta daninha, assim evitando sua competição com a cultura.

O uso de perda de biomassa ou índice de massa verde apresenta o efeito fênix (Gressel 2009). Quando a planta daninha sofre danos causados pelo efeito do herbicida, esta perde parte da sua massa, algumas chegando até a morte, porém as que não morrem conseguem sobreviver, se regenerar e se reproduzir. Não se sabe exatamente se após o efeito fênix as plantas daninhas se reproduzem mais, pois geram uma quantidade menor de sementes, porém as sementes geradas são reconhecidamente mais viáveis. A resposta que se deseja obter deve estar relacionada a como a planta se reproduz, portanto as respostas de perda de biomassa analisadas não são ideais.

Em campo, uma perda de biomassa em conjunto com fatores de competitividade entre as plantas daninhas e a cultura, normalmente acarreta a morte dessas plantas que tiveram uma perda considerável de biomassa, portanto, definindo um limitante para o que deve ser considerado como perda considerável de biomassa, pode ser emulada uma curva de resposta mortalidade a partir de uma curva de perda de biomassa.

Diferentes tipos de respostas são melhores, como a contagem de sementes produzidas viáveis que expressam diretamente a quantidade de plantas da próxima geração, porém esta contagem é de difícil obtenção devido ao tempo necessário para o experimento.

O tipo de resposta ideal é a mortalidade, que mede a dose ideal para a mortalidade 
de uma planta daninha. Devem ser feitas análise de mortalidade da mesma espécie de planta daninha para diversas etapas de crescimento. Estas respostas de diferentes etapas de crescimento reunidas são um quadro ideal do comportamento esperado numa população de plantas daninhas infestante de uma cultura. 


\section{Capítulo 3}

\section{Características dos principais modelos de resistência a herbicidas}

Neste capítulo são apresentados os principais modelos existentes na literatura. Estes modelos utilizam conceitos já comentados no Capítulo 2. Todos os modelos apresentados serviram como base para o desenvolvimento do modelo proposto.

\subsection{Primeiros trabalhos sobre a resistência a herbicidas}

A partir de 1956 os primeiros agentes químicos para controle de pestes (fungicidas, inseticidas e herbicidas) começaram a ser utilizados (Harper 1956). Desenvolvidos a partir da intensiva pesquisa realizada para desenvolvimento de fármacos rapidamente se tornaram os meios mais utilizados para controle devido ao menor tempo necessário na aplicação e ao custo inferior em relação aos métodos de manejo normalmente utilizados na época para o controle de pestes. Harper (1956) previu o aparecimento da resistência de plantas daninhas a herbicidas, assim como a resistência a inseticidas e a fungicidas. Em 1968, foram detectados casos de resistência em biótipos da planta Senecio vulgaris em Washington, EUA (Ryan 1970), nesta época casos de resistência aos fungicidas e aos inseticidas já eram conhecidos. Este aparente atraso na velocidade do aparecimento da resistência a herbicidas intrigou pesquisadores de diversas áreas. Gressel e Segel 
(1978) procuraram explicações para este aparente atraso em sua pesquisa, utilizando ferramentas de modelagem matemática e seu conhecimento da biologia das plantas para chegar às suas conclusões.

Em seu trabalho pioneiro, Gressel e Segel (1978) buscam as causas do aparecimento de resistência em plantas daninhas. Suas conclusões são que mudanças genéticas criam alterações na planta que alteram o modo como o herbicida age sobre a planta. Essas mudanças genéticas têm consequências fisiológicas, metabólicas ou fenotípicas, cada qual causando diferentes tipos de resistência e, consequentemente, diferentes níveis de resistência. Em relação à dose aplicada, o conceito é que a dose que seria letal ao indivíduo suscetível não irá matar o indivíduo resistente e afetará de alguma forma um indivíduo tolerante. Em Gressel e Segel (1979) os casos de tolerância conhecidos na época são apresentados.

O modelo apresentado em Gressel e Segel (1978) utiliza conceitos como mutação, tempo de vida de cada geração, pressão seletiva gerada por herbicidas, fitness, plasticidade Parkinsoniana e banco de sementes para definir suas equações.

O tempo de vida entre cada geração é apontado como fator chave para a grande diferença do aparecimento da resistência em plantas daninhas em relação às demais pragas. Já que fungos e insetos podem ter muitas gerações por ano, plantas daninhas se limitam a poucas gerações.

\subsection{Modelo de manejo de populações de plantas daninhas com resistência}

B. D. Maxwell (1990) introduziu um modelo populacional formado por submodelos, cada um representando uma fase da vida da planta daninha. São: banco de sementes, imigração de sementes, germinação, plantas adultas, imigração de pólen, produção de pólen, reprodução e produção de sementes. Cada submodelo pode também ser dividido em dois conjuntos de blocos iterativos, um para cada biótipo (resistente e suscetível). Os conjuntos interagem somente durante a recombinação genética e cada submodelo é descrito por uma equação de responsável pelo biótipo e equações que descrevem a frequência entre os genótipos. 
O tipo de dominância que expressa a resistência no modelo de B. D. Maxwell (1990) é recessiva homozigota, ou seja, somente o genótipo aa é responsável pelo biótipo resistente enquanto aA e AA são responsáveis pelo biótipo suscetível.

\subsubsection{Submodelo do banco de sementes}

O número de sementes suscetíveis e resistentes é uma função dada pelas taxas de mortalidade e germinação de cada biótipo. Ainda são adicionadas as sementes vindas da população adulta tratada e as imigrantes. As densidades de sementes resistentes $\left(x_{R}\right)$ e suscetíveis $\left(x_{S}\right)$ do banco antes da germinação são respectivamente dadas por:

$$
\begin{gathered}
x_{R}=x_{R, t-1}+x_{R, t-1}^{n}+x_{R, t}^{i}-\Psi_{R} x_{R, t-1}, \\
x_{S}=x_{S, t-1}+x_{S, t-1}^{n}+x_{S, t}^{i}-\Psi_{S} x_{S, t-1} .
\end{gathered}
$$

Após a germinação, as densidades de sementes resistentes e suscetíveis que se mantêm no banco até a próxima geração são:

$$
x_{R, t}=x_{R}-\delta_{R}\left(x_{R}\right), \quad x_{S, t}=x_{S}-\delta_{S}\left(x_{S}\right)
$$

em que o termo $\delta(x)$ define a densidade de sementes que germinarão, o qual será utilizado também no submodelo de germinação.

A frequência entre os biótipos neste submodelo, no tempo $t$, é obtido através da densidade de sementes do banco de sementes:

$$
\begin{array}{cc}
R_{t}=\frac{x_{R}}{x_{R}+x_{S}}, & S_{t}=\frac{x_{S}}{x_{R}+x_{S}} . \\
T_{t}^{x}=\frac{T_{t-1}^{x}\left(x_{R, t-1}+x_{S, t-1}\right)+T_{t-1}+x_{t}^{i}\left(T^{i}\right)}{x_{R}+x_{S}}, & U_{t}^{s}=S_{t}-T_{t} .
\end{array}
$$

\subsubsection{Submodelo de imigração de sementes}

Assume-se que as sementes imigrantes têm a mesma frequência de genótipos que a população onde estas sementes se originaram. A emigração de sementes não é considerada para simplificar o modelo.

A imigração de sementes é uma função de dispersão que envolve diversos parâmetros: tamanho e distância da fonte de origem das sementes, concentração de sementes na 
origem, dispersibilidade das sementes (peso, existência de meios de voo como plumas, asas, etc.) e presença de meios dispersivos (vento, chuvas, clima seco, etc.). Para cada espécie, estes parâmetros são específicos e um submodelo diferente de imigração de sementes deve ser definido. O modelo de B. D. Maxwell (1990) utiliza um submodelo de imigração de sementes $\left(x^{i}\right)$, baseado em um modelo que prevê o gradiente de doenças em plantas e dispersão de pólen pelo modelo de difusão de gradiente:

$$
x_{t}^{i}=\left(a_{x}\left(d+c_{o}\right)^{-b_{x}}\right)\left(c_{x}^{2} / c_{o}^{2}\right)
$$

com parâmetros que estão definidos na Tabela 3.1, dado por:

$$
x_{R, t}^{i}=x_{t}^{i}\left(R^{i}\right), \quad x_{S, t}^{i}=x_{t}^{i}\left(S^{i}\right)
$$

As proporções de cada genótipo das sementes imigrantes respeitam as da área de origem destas sementes e são denominadas $R^{i}$ (genótipo aa), $T^{i}$ (genótipo Aa) e $U^{i}$ (genótipo AA). A frequência do biótipo suscetível é $S^{i}=T^{i}+U^{i}$. Estas frequências serão consideradas como parâmetros fixados no submodelo, já que não se tem o conhecimento sobre o comportamento genético da área de origem das sementes imigrantes.

\subsubsection{Submodelo de germinação}

A percentagem de germinação de sementes que se tornarão plântulas (plantas jovens, recém germinadas) na população será:

$$
y_{R}=\delta_{R}\left(x_{R}\right), \quad y_{S}=\delta_{S}\left(x_{S}\right) .
$$

As densidades de plântulas dos biótipos resistente e suscetível que sobrevivem até a fase de madura é regulado por uma taxa de mortalidade natural que ocorre nesta fase são dadas por:

$$
y_{R, t}=y_{R}\left(\Psi_{R}^{n}\right), \quad y_{S, t}=y_{S}\left(\Psi_{S}^{n}\right)
$$

As frequências de plântulas de cada biótipo são dadas por:

$$
R_{t}=\frac{y_{R, t}}{y_{R, t}+y_{S, t}}, \quad S_{t}=\frac{y_{S, t}}{y_{R, t}+y_{S, t}} .
$$




\subsubsection{Submodelo de plantas adultas}

A densidade de plantas adultas de cada biótipo em idade reprodutiva na população são obtidas a partir do número de plântulas após o efeito do herbicida:

$$
y_{R, t}^{a}=y_{R, t}, \quad y_{S, t}^{a}=y_{S, t}-\rho\left(y_{S, t}\right) .
$$

A frequência de cada biótipo de plantas em fase adulta é dada por:

$$
R_{t}=\frac{y_{R, t}^{a}}{y_{R, t}^{a}+y_{S, t}^{a}}, \quad \quad S_{t}=\frac{y_{S, t}^{a}}{y_{R, t}^{a}+y_{S, t}^{a}} .
$$

O submodelo de plantas adultas inclui a influência do herbicida na transição da fase de plântula até a fase adulta. A eficácia do herbicida na população $(\rho)$ é baseada somente na sua eficácia sobre populações suscetíveis. A $\rho$ é equivalente ao controle relativo a populações suscetíveis não controladas. O controle através de herbicida só controla as plantas suscetíveis, portanto a parte resistente só pode ser controlada através dos processos de imigração ou fitness maior do biótipo suscetível em relação ao biótipo resistente.

\subsubsection{Submodelo de imigração de pólen}

Baseado no mesmo modelo usado para imigração de sementes (3.4), foi desenvolvido o submodelo de imigração de pólen, só que com diferentes parâmetros. As mesmas considerações usadas em (3.4) são feitas para esse submodelo:

$$
z_{t}^{i}=\left(a_{z}\left(d+c_{o}\right)^{-b_{z}}\right)\left(c_{z}^{2} / c_{o}^{2}\right)
$$

\subsubsection{Submodelo de produção de pólen}

A densidade de pólen produzida (z) por cada biótipo é:

$$
\begin{aligned}
z_{R, t} & =R_{t}\left(y_{R, t}^{a}+y_{S, t}^{a}-z_{t}^{i}\right)+R^{i}\left(z_{t}^{i}\right) \\
z_{S, t} & =S_{t}\left(y_{R, t}^{a}+y_{S, t}^{a}-z_{t}^{i}\right)+S^{i}\left(z_{t}^{i}\right)
\end{aligned}
$$


por sua vez, a frequência de cada biótipo no pólen produzido é dada por:

$$
\begin{array}{cc}
R_{t}=\frac{z_{R, t}}{z_{R, t}+z_{S, t}}, & S_{t}=\frac{z_{R, t}}{z_{R, t}+z_{S, t}}, \\
T_{t}^{z}=\frac{T_{t}^{x}\left(R_{t}+S_{t}\right)-z_{t}^{i}+T^{i}\left(z_{t}^{i}\right)}{R_{t}+S_{t}}, & U_{t}^{z}=S_{t}-T_{t}^{z} .
\end{array}
$$

\subsubsection{Submodelo de reprodução}

A probabilidade do alelo a entrar na recombinação genética de cada nova planta da população é baseada na frequência de cada genótipo na fase de produção de pólen. O fitness $k_{r}$ do pólen resistente em relação ao pólen suscetível é considerado também para o cálculo da probabilidade $P$ :

$$
P[\text { alelo a }]=\frac{0,5 T_{t}^{z}+k_{r} R_{t}}{k_{r} R_{t}+S_{t}}
$$

com os parâmetros definidos na Tabela 3.1.

O submodelo de reprodução deve assumir populações suficientemente grandes e recombinação aleatória para, assim, a probabilidade $P$ do alelo a participar da recombinação ser igual a sua frequência $p$ ao final da recombinação.

Em populações com tamanho reduzido ou reprodução somente com indivíduos próximos não há recombinação genética totalmente aleatória, o que cria um potencial para cruzamento consanguíneo. Esta mesma lógica nas plantas também inclui o fato de reproduzirem por autofecundação. Então, o submodelo de reprodução foi modificado para incluir o coeficiente de reprodução consanguíneo $f$, proposto por Wright (1984). A taxa de mutação $m$ está fixada no modelo em $10^{-6}$, dentro de uma faixa considerada normal. As proporções entre os genótipos após a reprodução são:

$$
\begin{array}{cc}
R_{t+1}=p^{2}(1-f)+p(f), & T_{t+1}=2(1-p)(p)(1-f), \\
U_{t+1}=(1-p)^{2}(1-f)+(1-p)(f), & S_{t+1}=T_{t+1}+U_{t+1} .
\end{array}
$$

O coeficiente de reprodução consanguíneo $f$ é dado por:

$$
f=\frac{1-2 m}{4 y^{s} m-2 m+1}
$$


em que $y^{s}$ é tamanho efetivo da população relacionado ao número de plantas se reproduzindo, dado por:

$$
y^{s}=\frac{1}{0,25\left(1 / y_{M}^{s}+1 / y_{F}^{s}\right)}
$$

em que $y_{M}^{s}$ indica o número de machos e $y_{F}^{s}$ de fêmeas.

Assume-se que a parte masculina (pólen) excede muito o da parte feminina (óvulos). Porém, $y_{F}^{s}$ é muito próximo da densidade de sementes produzidas enquanto $y_{M}^{s}$ não têm influência sobre a quantidade resultante de sementes. O $y_{M}^{s}$ influencia apenas na eficiência da reprodução.

Para ter a densidade de sementes de cada biótipo após a reprodução, a densidade de plantas que se reproduziram deve ser previamente calculada e então definidos quantas plantas serão de cada biótipo usando:

$$
y_{t}^{r}=y_{R, t}^{a}+y_{S, t}^{a}
$$

$\mathrm{e}$

$$
y_{R, t}^{r}=R_{t+1}\left(y_{t}^{r}\right), \quad y_{S, t}^{r}=S_{t+1}\left(y_{t}^{r}\right) .
$$

\subsubsection{Submodelo de produção de sementes}

O modelo de competição proposto por Firbank e Watkinson (1985) foi adaptado em B. D. Maxwell (1990) para prever a produção de cada biótipo de planta (C = competição). São separados os biótipos resistente e suscetível por causa de seus diferentes fitness. Outras inter e intra competições podem ser adicionadas ao modelo. $\mathrm{O}$ submodelo é descrito por:

$$
\begin{aligned}
C_{R, t} & =C_{R}^{\max }\left[1+A_{R}\left(y_{R, t}^{a}+l_{s r} y_{S, t}^{a}+l_{i R} y^{i}\right)\right]^{-h^{R}}, \\
C_{S, t} & =C_{S}^{\max }\left[1+A_{S}\left(y_{S, t}^{a}+l_{r s} y_{R, t}^{a}+l_{i S} y^{i}\right)\right]^{-h^{S}} .
\end{aligned}
$$

As sementes produzidas por unidade de área de cada biótipo é:

$$
x_{R, t}^{n}=C_{R, t}\left(y_{t}^{r}\right), \quad x_{S, t}^{n}=C_{S, t}\left(y_{t}^{r}\right)
$$

lembrando que $x_{R, t}^{n}$ e $x_{S, t}^{n}$ são termos do submodelo do banco de sementes da próxima geração $(t+1)$. 
Tabela 3.1: Definição dos parâmetros e variáveis do modelo de Maxwell

\begin{tabular}{|c|c|}
\hline $\begin{array}{l}\text { índice } R \\
\text { índice } S\end{array}$ & $\begin{array}{l}\text { Biótipo resistente } \\
\text { Biótipo suscetível }\end{array}$ \\
\hline$x$ & Sementes presentes no banco de sementes \\
\hline$x^{i}$ & Sementes imigrantes \\
\hline$p$ & Probabilidade do alelo a na recombinação genética \\
\hline$x^{n}$ & Sementes produzidas \\
\hline$y$ & Plantas jovens, sementes já germinadas \\
\hline$y^{a}$ & Plantas adultas, em fase de florescimento \\
\hline$y^{s}$ & Plantas que produziram pólen \\
\hline$y^{r}$ & Plantas maduras, já polinizadas e que produzirão sementes \\
\hline$y^{i}$ & Densidade de outras plantas na área \\
\hline$z$ & Fluxo de pólen produzido \\
\hline$z^{i}$ & Fluxo de pólen imigrante \\
\hline$R$ & Genótipo resistente \\
\hline$S$ & Genótipo suscetível (aa) \\
\hline$T$ & Genótipo suscetível heterozigoto (Aa) \\
\hline$U$ & Genótipo suscetível homozigoto (AA) \\
\hline$T^{x}$ & Genótipo suscetível heterozigoto $(\mathrm{Aa})$ do banco de sementes \\
\hline$T^{z}$ & Genótipo suscetível heterozigoto $(\mathrm{Aa})$ durante a polinização \\
\hline$k_{r}$ & Fitness do resistente em relação ao suscetível \\
\hline$f$ & Coeficiente de consanguinidade do gene de resistência \\
\hline$m$ & Taxa de mutação \\
\hline$\Psi$ & Taxa de mortalidade no banco de sementes \\
\hline$\Psi^{n}$ & Taxa de mortalidade de plantas jovens \\
\hline$\delta$ & Porcentagem de sementes que germinam \\
\hline$d$ & Distância entre a área tratada e a de origem das sementes imigrantes \\
\hline$c_{o}$ & Raio interior da área analisada \\
\hline$\rho$ & Eficácia do herbicida \\
\hline$a_{x}$ & Número de sementes produzidas por unidade de área \\
\hline$b_{x}$ & Declividade do gradiente difuso para sementes \\
\hline$c_{x}$ & Raio total da origem das sementes imigrantes \\
\hline$a_{z}$ & Quantidade de pólen produzido por unidade de área \\
\hline
\end{tabular}


Tabela 3.2: Definição dos parâmetros e variáveis do modelo de Maxwell (Cont.)

$b_{z} \quad$ Declividade do gradiente difuso para pólen

$c_{z} \quad$ Raio total da origem do pólen imigrante

A Área necessária para produção máxima

$l_{s r} \quad$ Influência da densidade de plantas $\mathrm{S}$ na produção de sementes $\mathrm{R}$

$l_{r s}$ Influência da densidade de plantas $\mathrm{R}$ na produção de sementes $\mathrm{S}$

$l_{i R}$ Influência da densidade de outras plantas na produção de sementes

$l_{i S} \quad$ Influência da densidade de outras plantas na produção de sementes

$h \quad$ Coeficiente de relação entre sementes produzidas e total da densidade

\subsection{Modelo da resistência múltipla e modelo da resistência ao glifosato}

Os modelos propostos em Diggle et al. (2003) e Neve et al. (2003) se assemelham em seus conceitos, porém, cada um tem um objetivo diferente. Diggle et al. (2003) visa exemplificar como diferentes métodos de aplicação combinada de herbicidas influenciam na resistência múltipla enquanto Neve et al. (2003) tenta prever as possibilidades de resistência da planta daninha Lolium rigidum ao herbicida glifosato.

Os modelos foram criados e implementados no programa de simulação populacional Stella (ISEE Systems 2011), utilizando conceitos de populações finitas de plantas daninhas e suas diversas fases da vida. A seguir o modelo de Diggle et al. (2003) é apresentado. A Tabela 3.3 apresenta os parâmetros e variáveis do modelo de Diggle.

Utilizando os mesmos conceitos de B. D. Maxwell (1990), o modelo de Diggle et al. (2003) pode ser dividido em diversas partes, cada uma representando uma fase do ciclo de vida da planta daninha, porém isto não caracteriza submodelos, apenas divisões dentro do ciclo de vida que este sim é um submodelo.

Cada genótipo tem um ciclo próprio, com algumas fases comuns a todos os genótipos, diferentemente do modelo de B. D. Maxwell (1990) no qual existem dois ciclos, um para cada biótipo. A divisão em submodelos adotada é diferente, existe o submodelo de ciclo de vida, o de competição e o de recombinação genética populacional. 
O submodelo de ciclo de vida de cada genótipo de planta daninha $\left(x_{i}\right.$, sendo $i$ cada genótipo) é dividido seguindo o mesmo raciocínio de outros modelos (B. D. Maxwell 1990, Cacho 1999) em que cada fase do ciclo de vida é representada e é necessário fases encadeadas no ciclo.

As fases são representadas por um sobrescrito após a variável $x_{i}$ (cada genótipo) ou $x$ (toda a população). As fases do ciclo de vida são: banco de sementes ( $\mathrm{s}=$ seed bank), sementes germinadas $(\mathrm{g}=$ germinated seeds $)$, plântulas jovens $(\mathrm{e}=$ established seedlings $)$, plantas maduras $(\mathrm{m}=$ mature plants $)$, sementes resultantes das plantas maduras $(\mathrm{sp}=$ seed produced $)$, sementes removidas do banco de sementes por outras causas além da germinação $(\mathrm{r}=$ seed removed $)$ e sementes adicionadas ao banco de sementes por contaminação de lotes de sementes da cultura $(\mathrm{a}=$ seed added $)$. Serão utilizadas em todas estas fases as medidas $x_{i} m^{-2}$.

A transição de indivíduos através das diversas fases (crescimento) obedece a probabilidades de sobrevida (ou de conseguir se reproduzir) a cada ciclo. Essa transição é representada por uma seta $(\rightarrow)$ que será uma fração da variável à esquerda, resultando na variável à direita. Cada geração ocorre no tempo $t$. A transformação de sementes até plantas adultas pode ser representada por:

$$
x_{i, t}^{m}=\left(x_{i, t}^{s}+x_{i, t}^{a}\right), \quad x^{s} \rightarrow x^{g}, \quad x^{g} \rightarrow e, \quad x_{i}^{e} \rightarrow x^{m} .
$$

O submodelo de competição define o total de sementes produzidas por todos os genótipos. É baseado no mesmo modelo de competição de Firbank e Watkinson (1985) que utiliza uma função hiperbólica reparametrizada. A produção de sementes é:

$$
x_{s p}=\frac{x^{m} x^{s p m a x} k x}{1+\left(x^{m} k x\right)+\left(x^{\prime m} k x^{\prime} A\right)}
$$

onde $x^{m}$ são plantas maduras, $x^{\prime m}$ são plantas da cultura, $x_{\text {spmax }}$ é o potencial máximo de sementes a serem produzidas, $k x$ é coeficiente do tamanho da planta, igual ao inverso da densidade $x^{m}$ quando a produção de sementes é metade de $x^{\text {spmax }}, k x^{\prime}$ é coeficiente do tamanho da cultura e $A$ é o coeficiente de antagonismo interespecífico entre planta daninha e cultura.

O total de novas sementes de cada genótipo que retorna ao banco de sementes $\left(x_{i, t}^{s n}\right)$ é baseado no total de sementes produzidas por cada genótipo $\left(x_{i, t}^{s p}\right)$ obedecendo a 
transição $x_{i, t}^{s p} \rightarrow x_{i, t}^{s n}$

A densidade de sementes do banco ao inicio de cada geração é:

$$
x_{i, t+1}^{s}=\left\{\left[1-x^{s} \rightarrow x^{g}\left(x_{i, t}^{s}+x_{i, t}^{a}\right)\right]\left(1-x^{s} \rightarrow x^{r w}\right)+x_{i, t}^{s n}\right\}\left(1-x^{s} \rightarrow x^{r s}\right)
$$

onde $x^{s} \rightarrow r s$ e $x^{s} \rightarrow r w$ são as transições de perda de sementes que ocorrem no verão $(\mathrm{rs}=$ removed in summer $)$ e inverno ( $\mathrm{rw}=$ removed in winter $)$, respectivamente.

A dinâmica genética é modelada para testar hipóteses de aumento de resistência a dois diferentes herbicidas, utilizando métodos de aplicação diferentes. Dois herbicidas hipotéticos com diferentes modos de ação (e, portanto, com resistências independentes uma da outra) são utilizados. A resistência a cada herbicida é conferida a planta através de um locus independente e segregado do outro. Esses loci são denominados A e B, respectivamente. Quatro biótipos de plantas são considerados, como a natureza da resistência é dominante, haverá nove genótipos. São: suscetível a ambos os herbicidas $\left(x_{a a b b}\right)$, resistente somente ao herbicida $1\left(x_{a A b b}\right.$ e $\left.x_{A A b b}\right)$, resistente ao herbicida 2 $\left(x_{a a B b}\right.$ e $\left.x_{a a B B}\right)$ e resistente a ambos os herbicidas $\left(x_{a A b B}, x_{A A b B}, x_{a A B B}\right.$ e $\left.x_{A A B B}\right)$.

A recombinação genética durante a reprodução em plantas daninhas pode ocorrer de duas maneiras: reprodução por autopolinização (autogâmica) ou por polinização de outras plantas (alogâmica). O modelo considera estes dois tipos de reprodução. O modo como a recombinação ocorre é considerado randômico entre todos os genótipos, limitado pelo número de indivíduos. Este processo é simulado pelo programa Stella.

Em Neve et al. (2003) são feitas modificações no modelo proposto inicialmente por Diggle et al. (2003) para simular a evolução da resistência ao glifosato da planta Lolium rigidum, uma planta daninha infestante das culturas australianas que apresenta casos de resistência a outros herbicidas.

Como principal modificação agora existem quatro coortes da planta, cada um representando um grupo de plantas com período de emergência diferente. Isto exige grandes mudanças no submodelo de competição, que agora além de lidar com a competição interespecífica entre a cultura e a planta daninha, lida também com a competição entre as coortes.

É também adicionado um modelo de previsão de emergência da planta daninha, que controla a interação entre as coortes. Os parâmetros foram obtidos empiricamente e foi 
usada uma parametrização através da função de Hill com dois parâmetros.

Tabela 3.3: Definição dos parâmetros e variáveis do modelo de Diggle

\begin{tabular}{ll}
\hline índice $s$ & Banco de sementes \\
índice $g$ & Sementes germinadas \\
índice $s$ & Plântulas jovens \\
índice $m$ & Plantas maduras \\
índice $s p$ & Sementes produzidas \\
índice $r$ & Sementes removidas \\
índice $a$ & Sementes adicionadas por outras formas sem ser as produzidas \\
índice $s n$ & Sementes que retornam ao banco de sementes \\
índice $r s$ & Sementes removidas no verão \\
índice $r w$ & Sementes removidas no inverno \\
\hline$x$ & Toda população de plantas \\
$x_{i}$ & Plantas de cada genótipo \\
$x_{s p m a x}$ & Potencial máximo de sementes a serem produzidas \\
$x^{\prime m}$ & Plantas maduras da cultura \\
$k x$ & Coeficiente do tamanho da planta daninhas (inverso da densidade) \\
$k x^{\prime}$ & Coeficiente do tamanho da cultura \\
$A$ & Coeficiente de antagonismo entre a planta daninhas e a cultura \\
\hline
\end{tabular}

\subsection{Modelo de evolução de resistência a pesticidas}

Os autores Crow e Kimura (1970) fornecem uma explicação detalhada da teoria da genética populacional. A partir dessa base, May e Dobson (1986) sugerem um modelo de evolução de resistência a pesticidas.

As gerações seguidas de plantas ocorrem de forma discreta, se houver diferenças de sobrevida de genótipos, essas frequências de alelos irão mudar em relação ao equilíbrio entre homozigotos e heterozigotos após a passagem de gerações. Esta evolução constitui o processo de seleção e é representada por

$$
q=-p q \frac{w_{A A} p-1+2 q-w_{a a} q}{w_{A A} p^{2}+2 p q+w_{a a} q^{2}}
$$


onde o alelo suscetível $\mathbf{A}$ e o alelo resistente a ocorrem respectivamente nas frequências $q_{t}$ e $p_{t}$ na geração $t\left(p_{t}+q_{t}=1\right)$. O genótipo aa é resistente, Aa e AA são suscetíveis. Aplicada uma determinada dose de pesticida, o fitness de cada um dos três genótipos serão definidos por $w_{A A}, w_{A a}$ e $w_{a a}$. sendo $A A$ para resistente, $A a$ e $a a$ para suscetível.

Reescrevendo (3.25), têm-se a frequência $p_{t}$ do gene a recursivamente dada por

$$
p_{t+1}=\frac{w_{A A} p_{t}^{2}+w_{A a} p_{t} q_{t}}{w_{A A} p_{t}^{2}+2 w_{A a} p_{t} q_{t}-w_{a a} q_{t}^{2}}
$$

Antes da aplicação do fator de pressão seletiva (herbicida), a frequência do alelo resistente $p_{t}$ será muito baixa $\left(10^{-10}\right)$. Assim, a razão $p_{t} / q_{t}$ será muito menor do que $w_{A a} / w_{A A}$ e $w_{a a} / w_{A a}$. Então, (3.26) é reduzida para

$$
p_{t+1}=\frac{w_{A a}}{w_{a a}} p_{t}
$$

Se o alelo a está presente em uma população não selecionada com frequência inicial $p_{0}$, pode-se determinar a partir de (3.27) o número aproximado de gerações $n$ que deve ocorrer antes que um grau de resistência notável apareça usando a relação:

$$
\frac{p_{f}}{p_{0}}=\left(\frac{w_{A a}}{w_{a a}}\right)^{n}
$$

onde $p_{0}$ é a frequência inicial do alelo resistente, $p_{f}$ é a frequência de limiar em que a resistência é significativamente reconhecida. A força da seleção $w_{A a} / w_{a a}$ determina o nível de pressão seletiva e do grau de dominância de a.

Definindo $T_{R}$ como sendo o tempo absoluto para atingir $p_{f}$ (limiar em que a resistência é significativamente reconhecida) e $T_{g}$ o tempo para uma população crescer, tem-se que $n=T_{R} / T_{g}$. Substituindo $n$ em (3.28), é possível prever aproximadamente o tempo $T_{R}$ onde certo nível de frequência $p_{f}$ é alcançado utilizando

$$
T_{R}=T_{g} \frac{\ln \left(\frac{p_{f}}{p_{0}}\right)}{\ln \left(\frac{w_{A a}}{w_{a a}}\right)} .
$$

Mesmo quando $p_{0}$ varia entre $10^{-5}$ e $10^{-16}, w_{A a} / w_{a a}$ entre $10^{-1}$ e $10^{-4}$ e $T_{g}$ sendo 1 ano, May e Dobson (1986) concluíram que $T_{R}$ deve pertencer ao intervalo de 10 a 100 
anos, assumindo seleção recorrente no período. A relação (3.28) é matematicamente análoga a uma relação alternativa obtida de forma independente e modificado em Gressel e Segel (1990) com:

$$
\frac{R_{n}}{R_{0}}=\left[1+\frac{F_{\alpha}}{b}\right]^{n}
$$

onde $R_{n}$ é a fração de sementes resistentes por unidade de área presente na população após $n$ anos de seleção recorrente, $R_{0}$ é a fração inicial de sementes resistentes, $b$ é o número médio de anos que uma semente permanece viável no banco de sementes. $F_{\alpha}$ é um fator que descreve a fecundidade relativa das sementes que sobreviveram. Nota-se que Gressel e Segel (1990) utiliza o termo pressão seletiva e $F_{\alpha}$ pode ser entendido como um fator de eficiência (sobrevida) da planta sobre toda uma geração de plantas em crescimento.

\subsection{Modelo de evolução através de pressão seletiva}

Considerando-se apenas as influências da pressão seletiva, pode-se definir sua influência sobre a distribuição genética de uma determinada população. A seguir, as funções de frequência genética dos alelos dominantes e recessivos em face da pressão seletiva são descritas seguindo os princípios descobertos por Fisher, Haldane e Wright (FHW), os três criadores da teoria moderna evolucionária (Britton 2003).

Considere a frequência de alelos da geração $t$, antes da recombinação genética, como sendo $p_{t}$ e $q_{t}$. Após recombinação aleatória, encontram-se os alelos combinados na sequência $A A_{t}, A a_{t}$ e $a a_{t}$, formando os genótipos $A A_{t}=p_{t}^{2}, A a_{t}=2 p_{t} q_{t}$ e $a a_{t}=q_{t}^{2}$. Estes valores de genótipos são conhecidos como equilíbrio de Handy-Weinberg e relações similares existem para alelos múltiplos. A probabilidade de sobrevivência até atingir maturidade reprodutiva terá a razão $w_{A A}: w_{A a}: w_{a a}$. Geralmente um destes valores da razão é considerado igual a 1 e os demais são descritos a partir deste. Portanto, na fase reprodutiva a razão dos genótipos $\mathbf{A A}, \mathbf{A a}$, aa apresenta a forma:

$$
w_{A A} p_{t}^{2}: 2 w_{A a} p_{t} q_{t}: w_{a a} q_{t}^{2}
$$


Então a razão entre as frequências dos alelos $\mathbf{A}$ e $\mathbf{a}$ se torna

$$
w_{A A} p_{t}^{2}+w_{A a} p_{t} q_{t}: w_{A a} p_{t} q_{t} w_{a a}+q_{t}^{2}
$$

Utilizando (3.32), obtém-se a equação da mudança de frequência do alelo A na próxima geração como

$$
p_{t+1}=\frac{w_{A A} p_{t}^{2}+w_{A a} p_{t} q_{t}}{w_{A A} p_{t}^{2}+2 w_{A a} p_{t} q_{t}+w_{a a} q_{t}^{2}}
$$

$\mathrm{Na}$ forma aditiva (3.33) pode ser escrita como

$$
p_{t+1}=p_{t}+g\left(p_{t}\right)
$$

onde $g\left(p_{t}\right)$ é o acréscimo esperado entre as gerações de indivíduos resistentes, dado por:

$$
g\left(p_{t}\right)=p_{t} q_{t} \frac{\left(w_{A A}-w_{A a}\right) p_{t}+\left(w_{A a}-w_{a a}\right) q_{t}}{w_{A A} p_{t}^{2}+2 w_{A a} p_{t} q_{t}+w_{a a} q_{t}^{2}}
$$

Este acréscimo diferencia a FHW do equilíbrio de Hardy-Weinberg e representa a evolução por pressão seletiva, definida pela diferença entre as vantagens evolutivas (fitness) $w_{A A}, w_{A a}$ e $w_{a a}$. 


\section{Capítulo 4}

\section{Modelo proposto de análise de populações de plantas daninhas resistentes a herbicidas}

\subsection{Concepção do modelo proposto}

Utilizando modelos apresentados no Capítulo 3 (Gressel e Segel 1978, B. D. Maxwell 1990, Diggle et al. 2003, Neve et al. 2003) foi desenvolvido um modelo que, além de explicar a dinâmica da população de plantas daninhas, explica também a dinâmica de mudança de características genéticas desta população que é submetida ao controle através de uma dose de herbicida.

Para definir o efeito da dose de herbicida sobre cada planta é utilizado o modelo curvas de dose-resposta (Seefeldt et al. 1995). Com base na metodologia de detecção de possíveis casos de resistência apresentada na Seção 2.4 é definido como será a curva de dose-reposta que corresponde à toda a população.

O modelo proposto não utiliza segregação entre os biótipos, conceito utilizado em outros modelos consagrados da literatura (Gressel e Segel 1978, B. D. Maxwell 1990, Diggle et al. 2003). A segregação cria divisões dentro da população que torna a análise do comportamento genético mais complexa, como o modelo proposto não possui segregação, é agora possível escolher diferentes dinâmicas de recombinação genética e possibilita a análise da resposta da planta e da população de plantas daninhas a diferentes doses de 
herbicida.

O modelo proposto, ao invés da a segregação entre os biótipos ou entre os genótipos, utiliza a frequência relativa para incluir as características genéticas de resistência na população em cada ciclo de vida.

\subsubsection{A recombinação genética}

A recombinação genética é o processo de separação e combinação de material genético durante a reprodução. Cada modelo da literatura sobre resistência (Gressel e Segel 1978, B. D. Maxwell 1990, Diggle et al. 2003) utiliza diferentes conceitos de como a recombinação genética influencia a dinâmica populacional. As espécies de plantas possuem diferentes métodos de reprodução, um único modelo de como ocorre a recombinação não pode ser considerado correto para explicar todas as espécies de plantas daninhas.

A teoria mendeliana de recombinação genética, assim como o modelo de HardyWeinberg são os conceitos usados como ponto de partida para todos os modelos de recombinação encontrados. Nessas duas teorias não existe o favorecimento de nenhum genótipo, portanto não acontece mudanças nas proporções encontradas desses genótipos.

Com os trabalhos de Wright (1972) e Fisher apresentado em Britton (2003), os desequilíbrios entre as frequências de determinados genes presentes na natureza são finalmente explicados. O estudo de populações limitadas em períodos limitados (Crow e Kimura 1970) trouxe melhorias aos modelos, pois consideram processos estocásticos relevantes que não são observados quando o tempo e o tamanho da população são infinitos.

Em plantas, outros fatores observados em determinadas espécies exigem modificações nos modelos. Plantas realizam processos próprios como autofecundação e reprodução por rizomas, causando comportamentos diferentes na dinâmica esperada da população. Conceitos diferentes, mas que causam alterações parecidas na dinâmica genética, são utilizados para representar comportamentos próprios das plantas em modelos de recombinação. Como exemplo, B. D. Maxwell (1990) utiliza as equações de Wright (1972) sobre cruzamentos consanguíneos para mimetizar os comportamentos de reprodução entre indivíduos próximos e o comportamento próprio de plantas.

A definição de um modelo de recombinação geral é uma tarefa complexa, pois cada 
planta analisada terá características diferenciadas. O objetivo do modelo proposto é explicar corretamente o aumento da dominância da resistência da população de plantas daninhas sobre condições de manejo normais, através de doses controladas de herbicida. O uso de uma equação mais simples, mas que consiga explicar bem a dinâmica de recombinação genética é, portanto, o foco que deve ser dado ao invés de equações complexas que consigam explicar todos os pormenores existentes. O modelo proposto é estruturado de forma que é possível alterar a parte que representa a recombinação genética possibilitando adequar o modelo à planta estudada.

\subsubsection{A eficácia da dose e o comportamento genético da população}

Cada planta daninha tem uma curva esperada de resposta à ação do herbicida e plantas com respostas próximas podem ser agrupadas de acordo com o biótipo resistente ou suscetível. Uma população de plantas daninhas que infesta uma determinada área é formada por uma mistura entre indivíduos resistentes e suscetíveis, portanto, uma curva de dose-resposta que corresponda a esta população deve contemplar ambos os biótipos.

Para a obtenção de uma curva dose-resposta que corresponda a toda a população estudada, é necessário a realização de vários ensaios com diferentes proporções de plantas resistentes e suscetíveis, assim pode-se conhecer a curva em qualquer condição de resistência que a população se encontre. Conhecendo a condição atual de resistência à herbicida da população de plantas daninhas, é possível definir quais ensaios devem ser considerados como reflexo da condição atual de resistência, e desses ensaios obter curvas de dose-resposta de toda população. Por este motivo, são normalmente estudadas curvas de dose-resposta de indivíduos resistentes ou suscetíveis.

A curva de dose-resposta de toda população deve apresentar características das curvas conhecidas dos dois biótipos. O esperado é que no caso da população ser formada apenas por plantas resistentes, a curva de dose-resposta terá apenas características da curva conhecida do biótipo resistente. No outro extremo, se a população for formada por plantas suscetíveis, a curva de dose-resposta terá características da curva do biótipo suscetível. Uma população com casos de resistência confirmada é, portanto, uma população mista entre indivíduos resistentes e suscetíveis e conforme a resistência se torna mais presente, esta população vai gradativamente se tornando somente resistente.

A curva de dose-resposta de uma população pode ser interpretada como a média 
formada pelas curvas individuais de toda esta população. Assim, pode-se caracterizar a dependência dos parâmetros da curva de dose-resposta de toda população em relação às curvas de dose-resposta de dois grupos característicos, os biótipos resistente ou suscetível, já que cada indivíduo pertence somente a um destes grupos.

A proporção entre indivíduos resistentes e suscetíveis mudará de acordo com o controle aplicado sobre as plantas daninhas e a proporção na próxima geração será um reflexo da eficácia do controle por herbicida. Esta eficácia influencia na velocidade com que os indivíduos suscetíveis são retirados do pool genético, sendo então este pool formado cada vez mais por resistentes.

Para cada diferente dose aplicada ocorre uma determinada pressão seletiva sobre toda a população de plantas daninhas, cada genótipo reage a esta pressão de forma diferenciada, devido aos fatores que geram a resistência.

\subsection{Modelo proposto para um herbicida}

O modelo é dividido em 3 submodelos: submodelo de recombinação genética, submodelo populacional e submodelo de dose-resposta. Os submodelos estão descritos a seguir.

\subsubsection{Submodelo de recombinação genética}

Para a maioria das plantas daninhas, o comportamento previsto pela equação FHW (Britton 2003) se mostra muito eficiente para representar espécies que possuem reprodução rápida, sexuada através do pólen gerando sementes, com gerações bem distintas uma das outras, com populações isoladas e de grande interação dentro da mesma população. Portanto, esta equação será a base para o submodelo de recombinação genética.

Porém, a equação FHW não contempla o banco de sementes. Uma forma de adequar a equação FHW para representar esse comportamento é considerar o banco como uma quantidade de material genético que não interage durante o processo, ou seja, as sementes dormentes não se tornam adultas e assim deixam de sofrer recombinação genética através da reprodução, apenas aquelas que se tornaram adultas estarão participando desse processo. 
Num banco de sementes altamente ativo, todas as sementes estão participando da recombinação genética e, por consequência, sofrendo processos de seleção, já num banco de sementes inativo não existe influência sobre os indivíduos que estão participando do processo de seleção já que estas sementes estão a maior parte do tempo adormecidas. No caso de um banco de sementes com comportamento normal, onde alguns dos indivíduos são expostos aos processos de seleção enquanto outros ficam inativos, há a necessidade de modificar a função de pressão seletiva da equação FHW (3.35) para representar essa diferente dinâmica gerada pelo banco de sementes dentro dos processos de seleção. Então (3.34) assume a forma:

$$
p_{t+1}=p_{t}+\alpha_{t} \chi g\left(p_{t}\right)=p_{t}+\alpha_{t} \chi p_{t} q_{t} \frac{\left(w_{A A}-w_{A a}\right) p_{t}+\left(w_{A a}-w_{a a}\right) q_{t}}{w_{A A} p_{t}^{2}+2 w_{A a} p_{t} q_{t}+w_{a a} q_{t}^{2}}
$$

onde $\alpha_{t}<1$ e $\chi>1$.

Na pressão seletiva é incluído um fator $\alpha_{t}$ entre as gerações de indivíduos resistentes, para assim atrasar a evolução da resistência. O fator $\alpha_{t}$ é a razão entre as novas sementes $x_{t}^{n}$ e as sementes presentes no banco de sementes $x_{t}$. Outro fator adicionado é um fator $\chi$ que representa um processo de autofecundação e reprodução entre indivíduos próximos.

O fator $\alpha_{t}$ representa uma diminuição do acréscimo à frequência do pool genético estudado $p$, já que apenas os indivíduos adultos sofrem processos de seleção e esse pool representa agora não somente as plantas vivas, mas também as sementes existentes no solo. Assim, é representado o comportamento do banco de sementes de manter indivíduos resistentes inativos.

Para relacionar a função de pressão seletiva a um único fator de pressão (a dose de herbicida), é determinado um coeficiente de pressão seletiva $s$ através de:

$$
s(u)=A
$$

onde $A$ é um coeficiente de ajuste definido pelo efeito que a dose deve causar na dinâmica da recombinação genética.

A razão entre as vantagens evolutivas é relacionada à pressão seletiva $s$ através de (4.1) através de:

$$
\left[w_{A A} w_{A a} w_{a a}\right]^{T}=D s+F
$$


com o vetor $F$ representando as vantagens evolutivas em condições naturais (sem a pressão seletiva agindo) de cada genótipo e o vetor $D$ é definido como vantagem evolutiva com presença do herbicida. Assim,

$$
D= \begin{cases}{\left[\begin{array}{lll}
1 & 1 & 0
\end{array}\right]^{T}} & \text { se dominante } \\
{\left[\begin{array}{lll}
1 & 0 & 0
\end{array}\right]^{T}} & \text { se recessivo }\end{cases}
$$

Quando não há diferenças entre os genótipos, os valores de cada item do vetor $F$ serão iguais a 1, que será o caso considerado. Pequenas diferenças entre esses valores representam vantagens naturais entre os biótipos, o que impede que, quando não há controle sobre a população, os genótipos se mantenham no equilíbrio de Hardy-Weinberg (Britton 2003).

Com auxílio do submodelo de recombinação genética, pode ser analisada qualquer mudança esperada na dinâmica de evolução genética. Ajustar corretamente os parâmetros que definem a força causada pela pressão seletiva sobre os indivíduos é essencial para que a previsibilidade deste submodelo ocorra conforme o que é esperado em ambiente real.

\section{Expressão da resistência}

A frequência $R_{t}$ do biótipo resistente (assim como o seu complementar $S_{t}=\left(1-R_{t}\right)$ do biótipo suscetível) pode ser inferida através do conhecimento do biótipo esperado da planta. Cada um dos três genótipos possíveis (dois homozigotos e um heterozigoto) pode gerar um biótipo diferente, dependendo das características dos alelos que formam cada genótipo. São estudados os casos de alelos dominantes ou recessivos, casos mais comuns e presentes em plantas daninhas.

No caso de alelo recessivo, somente o genótipo homozigoto AA $\left(p_{t}^{2}\right)$ é responsável pela resistência. Então, a proporção de indivíduos resistentes pode ser obtida através de

$$
R_{t}^{r}=p_{t}^{2}
$$

No caso de alelo dominante, além do genótipo homozigoto $\mathbf{A A}\left(p_{t}^{2}\right)$, o genótipo heterozigoto Aa $\left(2 p_{t}\left(1-p_{t}\right)\right)$ também é responsável pela resistência. Neste caso, a 
proporção de indivíduos resistentes pode ser obtida através de

$$
R_{t}^{d}=p_{t}^{2}+2 p_{t}\left(1-p_{t}\right)
$$

A função do alelo $p_{t}$ é obtida através da função FHW modificada em (4.1), dependendo da característica da planta estudada. Para obter a relação do alelo com o genótipo, são utilizados conceitos de Mendel e do equilíbrio de Hardy-Weinberg, presentes em Britton (2003). A FHW modificada é responsável pela dinâmica genética da resistência:

$$
R_{t}=\left\{\begin{array}{cc}
p_{t}^{2}+2 p_{t}\left(1-p_{t}\right) & , \text { se dominante } \\
p_{t}^{2} & , \text { se recessivo }
\end{array}\right.
$$

O submodelo de recombinação genética é formado por (4.1)-(4.4) e (4.7).

Tabela 4.1: Definição dos parâmetros e variáveis do submodelo de recombinação genética

\begin{tabular}{ll}
\hline & Definição \\
\hline$p_{0}$ & Frequência inicial do alelo \\
$p_{t}$ & Frequência do alelo na geração $t$ \\
$q_{t}$ & Frequência do alelo oposto $\left(q_{t}=1-p_{t}\right)$ na geração $t$ \\
$w_{A A}$ & Vantagem evolutiva do homozigoto resistente \\
$w_{A a}$ & Vantagem evolutiva do heterozigoto resistente/suscetível \\
$w_{a a}$ & Vantagem evolutiva do homozigoto suscetível \\
$s$ & Coeficiente de seleção \\
$R_{t}$ & Frequência de indivíduos resistentes na população \\
$R_{t}^{d}$ & $R_{t}$ para o caso dominante \\
$R_{t}^{r}$ & $R_{t}$ para o caso recessivo \\
$G R_{50 t}$ & Parâmetro que define $50 \%$ de resposta da curva dose-resposta na geração $t$ \\
$G R_{50 R}$ & $G R_{50}$ da curva de dose-resposta da planta resistente \\
$G R_{50 S}$ & $G R_{50}$ da curva de dose-resposta da planta suscetível \\
$c$ & Parâmetro que define o menor valor de resposta da curva dose-resposta \\
$d$ & Parâmetro que define o maior valor de resposta da curva dose-resposta \\
$b$ & Parâmetro que define a inclinação em torno de $G R_{50}$ da curva dose-resposta \\
$u$ & Dose utilizada na curva dose-resposta \\
$A$ & Fator de ajuste \\
$D$ & Vetor de vantagens evolutivas com presença do herbicida \\
$F$ & Vetor de vantagens evolutivas naturais \\
$\alpha_{t}$ & Plantas afetadas pela pressão seletiva. \\
\hline
\end{tabular}




\subsubsection{Submodelo de dose-resposta}

O submodelo de dose-resposta baseado na evolução da resistência proposto é inspirado na metodologia utilizada para detectar casos de resistência de plantas daninhas a herbicidas (Moss 1999, Seefeldt et al. 1995) e também na dinâmica de evolução genética da resistência. As curvas de dose-resposta de biótipos resistentes, obtidas através da metodologia de deteç̧ão de casos de resistência, e o índice de resistência obtido através destas são utilizados, então é obtida uma curva de dose-resposta que corresponde a uma população mista entre indivíduos de biótipos resistente e suscetível.

As seguintes suposições são consideradas para obter a função de dose-resposta do submodelo de dose-resposta:

1. o parâmetro $c$ (caracteriza a menor resposta possível) deve ser similar nas curvas de dose-resposta dos biótipos resistente e suscetível, pois trata-se da mortalidade mínima esperada da espécie de planta estudada;

2. o parâmetro $d$ (caracteriza a maior resposta possível) deve ser similar nas curvas de dose-resposta dos biótipos resistente e suscetível, caso contrário, o parâmetro $d$ do biótipo suscetível é considerado, pois nem sempre a mortalidade total é alcançada durante experimentos, como pode ser visto em López-Ovejero et al. (2006);

3. o parâmetro $b$ caracteriza o efeito do mecanismo de resistência (Tind et al. 2009, Peleg et al. 1997);

4. o parâmetro $G R_{50}$ varia de acordo com a proporção de indivíduos desta população mista.

Com base nas suposições 1-4, a função de dose resposta para a população mista é, então dada por

$$
\rho_{t}(u)=c_{s}+\frac{d_{s}-c_{s}}{1+\exp \left[b_{r}\left(\ln (u)-\ln \left(G R_{50 t}\right)\right)\right]}
$$

em que $d_{s}$ corresponde ao $d$ da curva de dose-resposta suscetível, $c_{s}$ corresponde ao $c$ da curva de dose-resposta suscetível, $b_{r}$ corresponde ao $b$ da curva de dose-resposta resistente e $G R_{50 t}$ é obtido por:

$$
G R_{50 t}\left(R_{t}\right)=R_{t} G R_{50 R}+\left(1-R_{t}\right) G R_{50 S}
$$


onde $R_{t}$ é obtido por (4.7) do submodelo de recombinação genética, $G R_{50 R}$ corresponde ao $G R_{50}$ da curva de dose-resposta resistente e $G R_{50 S}$ corresponde ao $G R_{50}$ da curva de dose-resposta suscetível.

Assim, a curva de dose-resposta de toda população irá variar com o tempo e de acordo com a presença cada vez maior de indivíduos resistentes nesta população. O submodelo de dose-resposta é formado por (4.8) e (4.9).

\subsubsection{Submodelo populacional}

O modelo proposto por Cacho (1999) apresenta a dinâmica da população de plantas considerando diversos coortes e a dose resposta mas não considera a resistência a herbicidas. Esse modelo se assemelha aos modelos propostos em B. D. Maxwell (1990) e Diggle et al. (2003) que representam o ciclo de vida. O ciclo de vida no submodelo populacional de Cacho (1999) é representado pelo modelo discreto:

$$
\begin{aligned}
y_{t} & =x^{g} \delta x_{t} \\
y_{t}^{a} & =(1-\rho(u)) y_{t} \\
x_{t}^{r} & =\exp \left[\gamma \ln y_{t}^{a} /\left(\mu+\varepsilon \ln y_{t}^{a}\right)\right] \\
x_{t}^{n} & =\kappa x_{t}^{r}-\eta+\xi \\
x_{t+1} & =x_{t}^{n}+(1-\Psi)(1-\delta) x_{t}
\end{aligned}
$$

com variáveis e parâmetros definidos na Tabela 4.2. Considera-se $x_{t}^{r}$ nulo quando $y_{t}^{a}$ for menor que 0,5 , porque o resultado de (4.12) tende ao infinito quando $y_{t}^{a}$ se aproxima de zero.

O modelo proposto de análise de populações de plantas daninhas resistentes a herbicidas é formado pelos submodelos apresentados (4.1)-(4.4) (4.7)-(4.14).

\subsection{Modelo com segregação do banco de sementes em bióti- $\operatorname{pos}(\mathrm{MSBSB})$}

Nos modelos encontrados na literatura são considerados duas populações distintas (segregadas), uma de cada biótipo, onde a interferência genética entre as populações é 
Tabela 4.2: Definição dos parâmetros e variáveis do submodelo populacional

\begin{tabular}{ll}
\hline$x_{t}$ & Densidade do banco de sementes $\left(m^{-2}\right)$ no início da geração $t$ \\
$y_{t}$ & Densidade de plantas jovens $\left(m^{-2}\right)$ na geração $t$ \\
$y_{t}^{a}$ & Densidade de plantas emergentes $\left(m^{-2}\right)$ que chegam à fase adulta \\
$x_{t}^{r}$ & Densidade de sementes $\left(m^{-2}\right)$ resultantes da reprodução da planta daninha \\
$x_{t}^{n}$ & Novas sementes adicionadas ao banco de sementes $\left(m^{-2}\right)$ na geração $t$ \\
$x^{g}$ & Sementes germinadas que emergiram $\left(m^{-2}\right)$ \\
$\delta$ & Taxa de germinação anual das sementes da planta daninha \\
$u$ & Dose de herbicida aplicada (litro $\left.h a^{-1}\right)$ \\
$\rho_{t}$ & Eficácia causada pela dose de herbicida na geração $t$ \\
$\phi, \mu, \varepsilon$ & Coeficientes de $x_{t}^{r}$ \\
$\kappa$ & Taxa de sobrevivência de novas sementes \\
$\eta$ & Retirada de sementes na colheita \\
$\xi$ & Importação de sementes (vento, pássaros, etc) \\
$\Psi$ & Indice de mortalidade de sementes dormentes \\
\hline
\end{tabular}

pequena, apenas diferenciando o efeito causado pelo herbicida sobre a dinâmica populacional. Considerando as formas de segregação normalmente utilizadas nos modelos, foi realizado um modelo com segregação, a fim de testar a hipótese do modelo proposto, que não possui segregação, ter resultados semelhantes aos modelos encontrados na literatura.

A estrutura do modelo com segregação do banco de sementes utiliza os mesmos conceitos de B. D. Maxwell (1990), onde existem dois ciclos de vida para cada um dos biótipos e a proporção entre resistentes e suscetíveis em cada um destes ciclos define a frequência genética a ser considerada.

O modelo populacional apresentado em Cacho (1999) é utilizado como base. Duas realizações desse modelo são utilizadas, uma para cada biótipo ( $R$ para resistentes e $S$ para suscetíveis). A condição inicial para a divisão da população em cada um dos biótipos é dada por

$$
\begin{aligned}
& x_{R, 0}=x_{0} R_{0} \\
& x_{S, 0}=x_{0}\left(1-R_{0}\right)
\end{aligned}
$$

com $R_{0}$ a proporção inicial de plantas resistentes e $x_{0}$ o banco de sementes inicial. A realização $j=R$ ou $S$ para cada um dos biótipos analisados é obtida a partir de 


$$
\begin{aligned}
\rho_{j}(u) & =c_{j}+\frac{d_{j}-c_{j}}{1+\exp \left[b_{j}\left(\ln (u)-\ln \left(G R_{j, 50}\right)\right)\right]} \\
y_{j, t} & =x_{j}^{g} \delta x_{j, t} \\
y_{j, t}^{a} & =\left(1-\rho_{j}(u)\right) y_{j, t} \\
x_{j, t}^{r} & =\exp \left[\gamma \ln y_{j, t}^{a} /\left(\mu+\varepsilon \ln y_{j, t}^{a}\right)\right] \\
x_{j, t}^{n} & =\kappa x_{j, t}^{r}-\eta+\xi \\
x_{j, t+1} & =x_{j, t}^{n}+(1-\Psi)(1-\delta) x_{j, t} .
\end{aligned}
$$

A resposta de cada biótipo a dose de herbicida é diferente, o que significa diferenças de mortalidade $\left(\rho_{j}\right)$ e, consequentemente, diferenças na proporção de cada biótipo no total da população de plantas. Cada realização terá sua própria função de dose-resposta.

$\mathrm{Na}$ fase reprodutiva, todas as sementes adicionadas ao banco devem ser consideradas, então é possível saber a frequência genética da população esperada a partir de

$$
\begin{aligned}
x_{t+1} & =\sum_{j=1}^{2} x_{j, t+1} \\
R_{t} & =x_{R, t+1} / x_{t+1} .
\end{aligned}
$$

Este modelo com segregação do banco de sementes em biótipos não contempla a dinâmica genética que existe na população de plantas daninhas. Neste modelo é possível observar a dinâmica de aumento ou redução da população. A dinâmica genética pode ser representada pelo submodelo de recombinação genética, que por si só consegue representar a dominação da população pelo gene responsável pela resistência. O modelo com segregação do banco de sementes em biótipos (MSBSB) é formado por duas realizações de (4.15)-(4.18), uma para cada biótipo e (4.19).

\subsection{Modelo de características genéticas da população (MCGP)}

A partir do trabalho apresentado em Britton (2003) sobre genética populacional, pode ser definido um modelo simples para representar o estado de uma característica genética presente na população. Com a adição de pressão seletiva criada pelo herbicida, pode ser representada como a característica de resistência a este herbicida estará 
presente na população ao longo do tempo.

O modelo de características genéticas da população é representado por (3.34) e (3.35), com o coeficiente de pressão seletiva dada por (4.3) e o vetor de vantagens evolutivas dada por (4.4).

Então, é possível determinar a razão entre a frequência dos genótipos AA, Aa (responsáveis pela resistência) e aa (suscetível) através de

$$
p_{t}^{2}: 2 p_{t} q_{t}: q_{t}^{2}
$$

Neste modelo de características genéticas da população não é possível observar mudanças no tamanho da população, apenas alterações de suas características genéticas. O modelo de características genéticas da população é formado por (3.34),(3.35), (4.3), (4.3) e (4.19).

\subsection{Modelo proposto para múltiplos herbicidas}

O modelo proposto para múltiplos herbicidas tem como objetivo estudar o uso de herbicidas em sistema de rotação de herbicidas, um método de manejo utilizado atualmente. Neste sistema, dois herbicidas são utilizados, um de cada vez a cada ciclo de vida da planta daninha. A escolha desses herbicidas visa suprimir o aparecimento de indivíduos resistentes a qualquer um destes herbicidas.

Normalmente, existe o herbicida recomendado e o chamado alternativo, utilizado quando se verifica que o herbicida recomendado não está sendo eficaz em seu controle. Essa perda de eficácia do herbicida sobre a planta está diretamente relacionada ao problema da resistência. Com o uso intensivo de herbicidas, a resistência aos herbicidas recomendados já é bem estudada e se tem um conhecimento de como essa resistência funciona (Vargas et al. 2006). Já a resistência ao herbicida alternativo apresenta novos desafios, pois quando surge a resistência a este herbicida alternativo, pode ocorrer interação com a resistência ao herbicida recomendado. Os modos como estas duas resistências interagem não são completamente conhecidos.

O tempo de rotação e o momento da troca podem ser otimizados, e é de extrema importância no planejamento do uso de herbicida já que nem sempre a troca constante 
pode ser a escolha correta de manejo.

O modelo apresentado em Diggle et al. (2003) explica como a resistência múltipla funciona. Segundo Diggle et al. (2003), a resistência múltipla são duas resistências completamente independentes uma da outra na mesma espécie, portanto, podem ocorrer resistências a somente um dos herbicidas ou aos dois herbicidas na mesma população.

A resistência cruzada é mais complexa de ser modelada devido à interação que ocorre na resistência aos dois herbicidas, já que essa resistência é gerada pelo mesmo mecanismo de resistência.

Ainda existem peculiaridades genéticas no modo como resistências diferentes, controladas por diferentes genes, podem interagir. Os modelos não são capazes de representar a recombinação e a proporção genética quando há segregação destes genes (neste caso, se representa dois genes como um único gene). Há ainda a interação que pode ocorrer quando o herbicida alternativo reduz a quantidade de indivíduos do biótipo resistente ao herbicida recomendado, gerando um caso peculiar de pressão seletiva inversa: o gene resistente ao herbicida recomendado é desfavorecido quando é aplicado o herbicida alternativo ou o contrário.

A resistência cruzada é definida como a resistência a vários herbicidas causada por apenas um gene (ou um grupo de genes totalmente não segregados, o que em representação genética pode ser considerado um único gene), portanto os herbicidas aplicados sobre plantas com resistência cruzada apresentam uma rápida evolução a ambos herbicidas, não importando qual é aplicado, o que difere entre os herbicidas é que cada um tem uma pressão seletiva diferenciada sobre a população, um mais eficaz terá uma influência grande na velocidade do aumento da resistência enquanto que com baixa eficácia também aumentará a resistência, só que de forma mais suave.

Na resistência múltipla a mesma planta consegue de alguma forma se tornar resistente a mais de um tipo de herbicida. Normalmente se considera que a resistência múltipla é causada por genes diferentes e totalmente segregados, de forma que as resistências sejam independentes uma da outra. Qualquer dependência altera o modo como deve ser considerada a influência de um herbicida em outro, no modelo podem ser feitas certas considerações sobre a dependência existente entre as resistências.

Em caso de alguma relação de dependência entre os genes que controlam as resistên- 
cias, o comportamento genético pode ser drasticamente alterado. Como essa relação ocorre não é conhecido para todas as plantas, algumas hipóteses podem ser levantadas. Quando um gene responsável pela resistência ao herbicida 1 está presente no mesmo cromossomo que o gene responsável pela resistência ao herbicida 2, tem-se claramente um caso de segregação total, podendo até mesmo definir está resistência como cruzada no modelo ao invés de múltipla, apesar do conhecimento de que os mecanismos de resistência não são iguais.

Outra abordagem poderá ser utilizada: uma certa proporção da população contém os genes de resistência ao herbicida 1, dentro desta proporção de resistentes ao herbicida 1, existe uma certa proporção de indivíduos resistentes ao herbicida 2. A diferença é que necessariamente a resistência ao herbicida 1 deve haver na planta para que haja resistência ao herbicida 2 .

A proposta para o uso de múltiplos herbicidas é alterar o modelo proposto para que existam múltiplas realizações na parte genética e de resposta ao herbicida. Esta modificação no modelo proposto consegue representar dependências entre as resistências. Modificando (4.2) para:

$$
s_{j}\left(u_{i}\right)=A_{i j}, \quad A \in \Re^{n \times m}
$$

onde $s_{j}\left(u_{i}\right)$ é o vetor da dose $u_{i}$ para a pressão seletiva $j$. A matriz $A$ reflete a eficácia da dose de todos os herbicidas analisados e poderá ter diferentes estruturas para cada tipo de resistência. Haverá $i$ diferentes loci controlando a genética da resistência. Quando $i=j$ é um caso de resistência múltipla. Se $i<j$ ocorre que um mecanismo gera a resistência a mais de um herbicida, então é caso de resistência cruzada.

A matriz $A$ normalmente será formada por uma única linha não nula (no caso de representação de resistência múltipla) ou apenas a diagonal principal não nula (no caso de representação de resistência cruzada). Caso exista $A_{i j}$ não nulo além da linha ou da diagonal principal, implica um efeito de um herbicida sobre a resistência a outro herbicida, ou seja, uma dependência entre os efeitos dos herbicidas.

As equações seguintes descrevem o submodelo de recombinação genética e de dose- 
resposta e são reescritas de forma a representar múltiplas pressões seletivas:

$$
\begin{aligned}
& s^{i}\left(u_{i}\right)=A_{i} \\
& D^{i}= \begin{cases}{\left[\begin{array}{lll}
1 & 1 & 0
\end{array}\right]^{T}} & , \text { se dominante } \\
{\left[\begin{array}{lll}
1 & 0 & 0
\end{array}\right]^{T}} & \text {, se recessivo }\end{cases} \\
& W^{i}=\left[\begin{array}{lll}
w_{x}^{i} & w_{y}^{i} w_{z}^{i}
\end{array}\right]=D^{i} s^{i}+F, \\
& p_{t+1}^{i}=p_{t}^{i}+\alpha^{i} \chi g\left(p_{t}^{i}\right)=p_{t}^{i}+\alpha \chi p_{t}^{i} q_{t}^{i} \frac{\left(w_{A A}^{i}-w_{A a}^{i}\right) p_{t}^{i}+\left(w_{A a}^{i}-w_{z}^{i}\right) q_{t}^{i}}{w_{A A}^{i}\left(p^{i}\right)_{t}^{2}+2 w_{A a}^{i} p_{t}^{i} q_{t}^{i}+w_{a a}^{i}\left(q^{i}\right)_{t}^{2}} \\
& R_{t}^{i}=\left\{\begin{array}{cc}
\left(p_{t}^{i}\right)^{2}+2 p_{t}^{i}\left(1-p_{t}^{i}\right) & , \text { se dominante } \\
\left(p_{t}^{i}\right)^{2} & , \text { se recessivo }
\end{array},\right. \\
& G R_{50 t}^{i}\left(R_{t}^{i}\right)=R_{t}^{i} G R_{50 R}^{i}+\left(1-R_{t}^{i}\right) G R_{50 S}^{i}, \\
& \rho_{t}^{i}\left(u_{i}\right)=c_{s}+\frac{d_{s}-c_{s}}{1+\exp \left[b_{r}\left(\ln \left(u_{i}\right)-\ln \left(G R_{50 t}^{i}\right)\right)\right]},
\end{aligned}
$$

com parâmetros descritos na Tabela 4.1.

Como só será aplicado um herbicida em cada período de emergência, as respostas $\rho^{i}$ funcionarão somente uma de cada vez, não sendo necessário modificar (4.8). Não será simulado o efeito do uso combinado de dois herbicidas, um meio ineficaz para controlar a resistência (Diggle et al. 2003). As demais equações (4.10)-(4.14) não sofrem modificação. 


\section{Capítulo 5}

\section{Resultados de simulações}

Os parâmetros utilizados no submodelo populacional foram tirados de Jones e Cacho (2000). No submodelo populacional adotam-se como condição inicial do banco de semente $x_{0}=500$ sementes por $m^{2}$. O período de simulação deve ser suficiente para a estabilização do banco de sementes. Considera-se que o banco de sementes não sofre interferências externas durante o período de simulação (imigração ou emigração).

No submodelo de recombinação genética com pressão seletiva a resistência presente para ambos os herbicidas é considerada como sendo dominante (a maioria das plantas daninhas com resistência aos herbicidas analisados possui o gene do tipo dominante (Tranel e Wright 2002)). A escolha dos coeficientes de ajuste $\alpha_{t}=x_{t}^{n} / x_{t}$ e $\chi=2$ segue a metodologia apresentada em Britton (2003), em que o coeficiente de pressão seletiva $s$ deve estar entre certos valores. A mudança no coeficiente de ajuste altera a velocidade do aumento da resistência na população. Todos os genótipos não possuem diferenças em seus fitness quando não há a presença do herbicida $\left(F=\left(\begin{array}{lll}1 & 1 & 1\end{array}\right)^{T}\right)$. A frequência de resistência inicial é considerada detectável $(p=0,1)$. 
Tabela 5.1: Valores dos parâmetros do submodelo populacional utilizados nas simulações

\begin{tabular}{lc}
\hline Parâmetros do submodelo populacional & \\
\hline$\delta$ & 0,30 \\
$\psi$ & 0,20 \\
$\eta\left(\right.$ sementes $\left./ m^{2}\right)$ & 0 \\
$\xi\left(\right.$ sementes $\left./ m^{2}\right)$ & 0 \\
$\kappa$ & 0,80 \\
$x^{g}$ & 0,50 \\
$\gamma$ & 6,80 \\
$\mu$ & 2,00 \\
$\epsilon$ & 0,67 \\
\hline
\end{tabular}

\subsection{Estudo de caso: Bidens subalternans}

Nesta seção é apresentado um estudo de caso de resistência a herbicida de uma importante planta daninha presente nas regiões tropicais, a Bidens subalternans. Os parâmetros de dose-resposta para os biótipos suscetíveis e resistentes da Bidens subalternans aos herbicidas atrazine e nicosulfuron foram obtidos em casa de vegetação na Embrapa Milho e Sorgo, Sete Lagoas - MG.

Na Tabela 5.2 apresentam-se os parâmetros da curva log-logística do submodelo de dose-resposta. A Figura 5.1(a) apresenta as curvas dos biótipos resistente e suscetível para o herbicida atrazine, a Figura 5.1(b) representa o efeito do herbicida nicosulfuron. A resistência ao herbicida atrazine pode ser considerada um caso de tolerância devido ao seu baixo índice de resistência $I_{r}$. Os coeficientes de pressão seletiva são adotados como sendo $s=0,04$ para atrazine e $s=0,26$ para nicosulfuron.

Tabela 5.2: Parâmetros de dose-resposta da planta Bidens subalternans resistente e suscetível aos herbicidas atrazine e nicosulfuron

\begin{tabular}{|c|c|c|c|c|c|c|}
\hline Herbicida & $I_{r}$ & Biótipo & $\mathrm{b}$ & $\mathrm{c}$ & $\mathrm{d}$ & $G R_{50}$ \\
\hline \multirow[t]{2}{*}{ atrazine } & 2,078 & $\overline{\mathrm{R}}$ & $-0,998831$ & 0,820237 & 103,767836 & 1598,556398 \\
\hline & & $\mathrm{S}$ & $-1,542981$ & $-2,018672$ & 101,49439 & 769,451568 \\
\hline \multirow[t]{2}{*}{ nicosulfuron } & 12,85 & $\mathrm{R}$ & $-0,573644$ & $-0,517653$ & 100,344574 & 62,129090 \\
\hline & & $\mathrm{S}$ & $-0,584985$ & 0,281898 & 101,000008 & 4,836248 \\
\hline
\end{tabular}




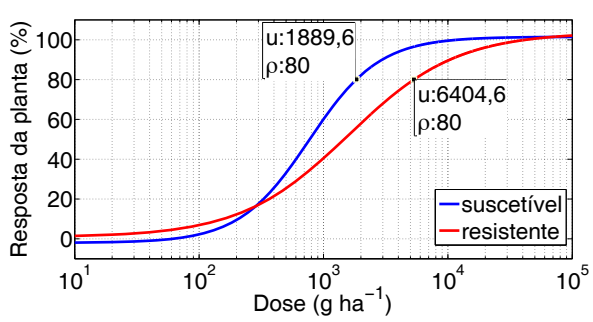

(a) atrazine

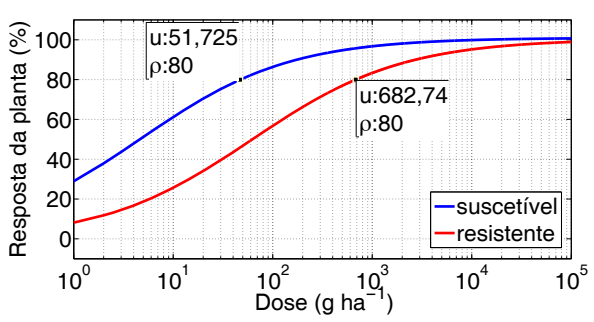

(b) nicosulfuron

Figura 5.1: Curvas de dose-resposta dos herbicidas atrazine e nicosulfuron utilizando os parâmetros encontrados na Tabela 5.2 e seus respectivos parâmetros $G R_{80}$ de cada curva.

\subsubsection{Simulação do modelo proposto para um herbicida}

Na simulação do modelo proposto será utilizado um herbicida em cada caso, atrazine e nicosulfuron. A dose será fixada no valor de $G R_{80}$ da curva de dose-resposta suscetível (destacado na Figura 5.1). O comportamento do banco de sementes, da frequência de gene de resistência e da frequência de indivíduos resistentes esperada e a resposta a dose aplicada de herbicida são representados nas Figuras 5.2 e 5.3.

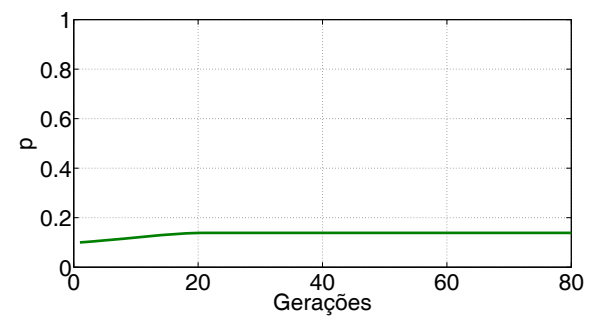

(a)

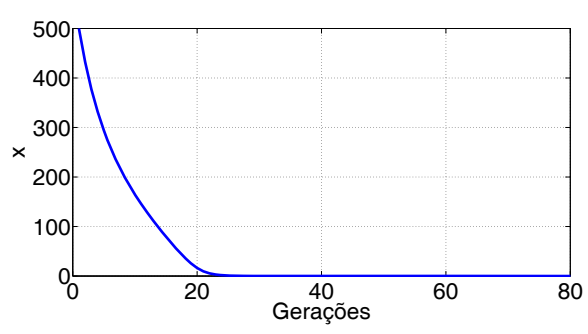

(c)

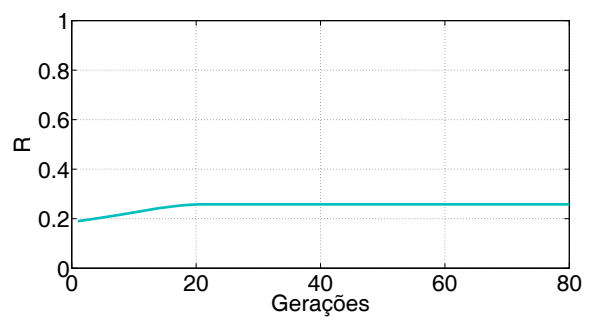

(b)

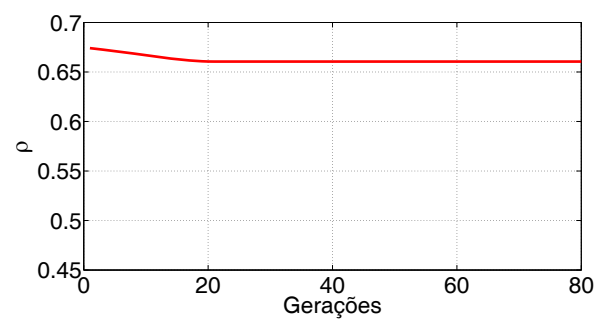

(d)

Figura 5.2: Comportamento genético populacional da Bidens subalternans sob o efeito do herbicida atrazine. (a) Frequência do gene resistente, (b) Frequência de indivíduos resistentes, (c) Tamanho do banco de sementes e (d) Eficácia da dose. 


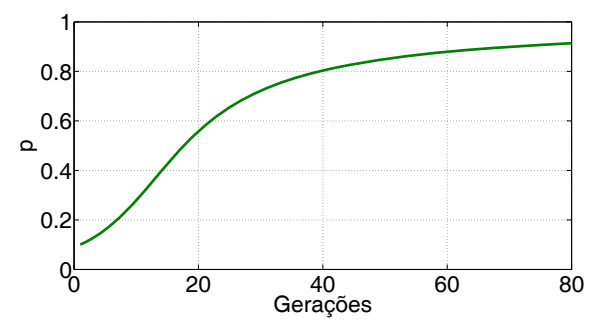

(a)

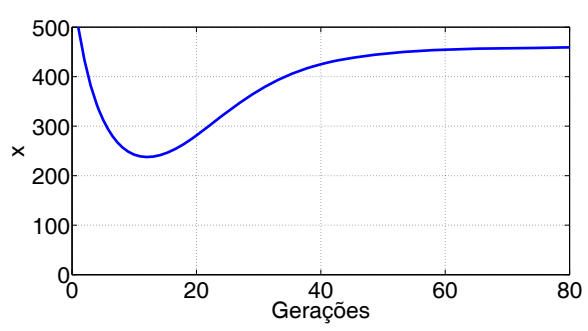

(c)

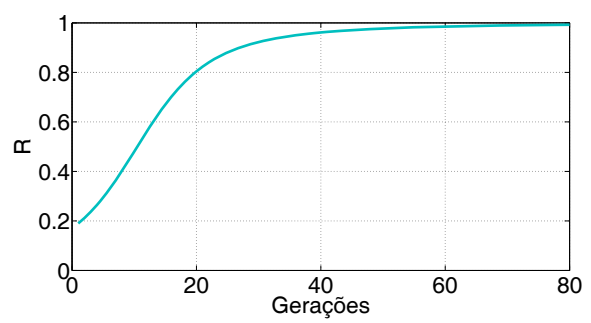

(b)

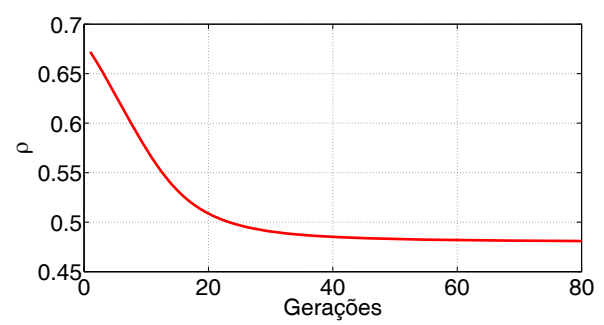

(d)

Figura 5.3: Comportamento genético populacional da Bidens subalternans sob o efeito do herbicida nicosulfuron. (a) Frequência do gene resistente, (b) Frequência de indivíduos resistentes, (c) Tamanho do banco de sementes e (d) Eficácia da dose.

O banco de sementes apresenta uma queda inicial e uma tendência a se recuperar (devido ao aparecimento de resistência). Se essa tendência não for controlada, o banco de sementes será tomado por indivíduos resistentes e haverá perda do controle (o herbicida não terá mais eficácia sobre as plantas). Na Figura 5.2 esta tendência de aparecimento de resistência não ocorre devido a pouca diferença de resposta ao herbicida entre indivíduos resistentes e suscetíveis, o que torna a dose utilizada eficaz também em indivíduos tolerantes.

\subsubsection{Simulação do MSBSB e do MCGP para o herbicida nicosulfuron}

Com os mesmos dados e parâmetros utilizados nas simulações do modelo proposto para um herbicida são realizadas simulações com o MSBSB e com o MCGP. A análise é feita somente para o herbicida nicosulfuron. O objetivo é comparar os resultados destes modelos com os resultados do modelo proposto para um herbicida. Para facilitar a comparação, os resultados da Figura 5.3 estão repetidos na Figura 5.4. 


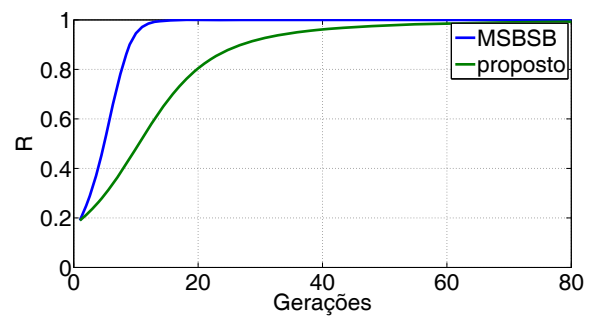

(a)

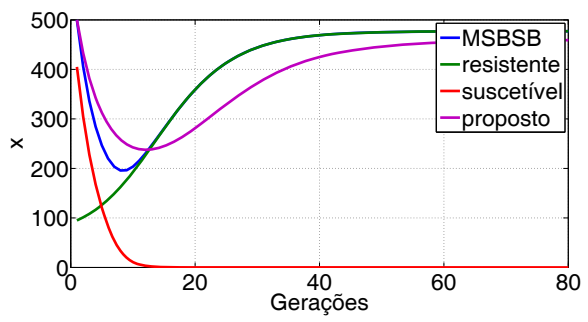

(b)

Figura 5.4: Simulação do MSBSB da Bidens subalternans sob o efeito do herbicida nicosulfuron. (a) Frequência de indivíduos resistentes e (b) Tamanho do banco de sementes.

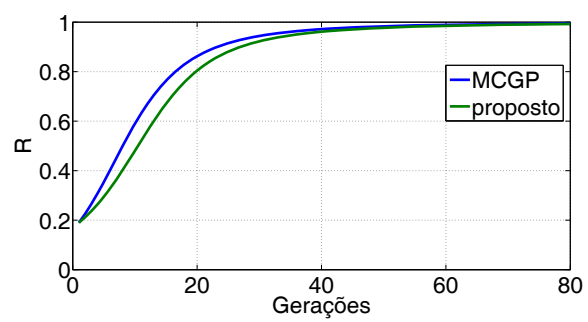

(a)

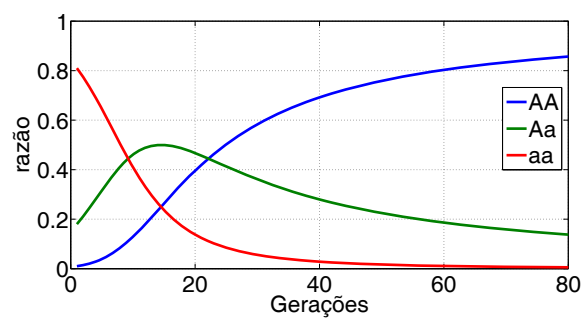

(b)

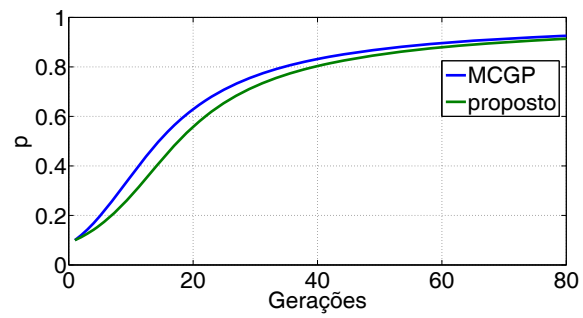

(c)

Figura 5.5: Simulação do MCGP da Bidens subalternans sob o efeito do herbicida nicosulfuron. (a) Frequência de indivíduos resistentes (b) Razão entre os genótipos e (c) Frequência do gene de resistência.

\subsection{Estudo de caso: Bidens pilosa}

Nesta seção é apresentado um estudo de caso da evolução da resistência de uma outra importante planta daninha presente nas regiões tropicais, a Bidens Pilosa. É uma planta originária da América tropical, largamente dispersa em várias regiões do mundo, ocorrendo com maior intensidade na América do Sul. No Brasil, é encontrada em praticamente todo o território, com maior concentração nas áreas agrícolas da Região Centro-Sul, onde se constitui numa das mais importantes plantas infestantes, tanto de culturas anuais como de perenes (Adegas et al. 2003). 
São utilizados nas simulações os parâmetros apresentados em López-Ovejero et al. (2006) referentes aos biótipos suscetíveis e resistentes da Bidens pilosa aos herbicidas chlorimuron-ethyl e imazetaphyr. Na Tabela 5.3 apresentam-se os parâmetros da curva log-logística do submodelo de dose-resposta. A Figura 5.2(a) apresenta as curvas dos biótipos resistente e suscetível para o herbicida chlorimuron-ethyl, a Figura 5.1(b) representa o efeito do herbicida imazetaphyr. A resistência ao herbicida imazetaphyr pode ser considerada um caso de tolerância devido ao seu baixo índice de resistência $\left(I_{r}\right)$. Os coeficientes de pressão seletiva são adotados como sendo $s=0,4$ para chlorimuron-ethyl e $s=0,02$ para imazetaphyr.

Tabela 5.3: Parâmetros no modelo log-logístico de dose resposta da planta Bidens pilosa resistente e suscetível aos herbicidas chlorimuron-ethyl e imazetaphyr

\begin{tabular}{ccccccc}
\hline Herbicida & $I_{r}$ & Biótipo & $\mathrm{b}$ & $\mathrm{c}$ & $\mathrm{d}$ & $G R_{50}$ \\
\hline chlorimuron-ethyl & 20,543 & $\mathrm{R}$ & $-1,752$ & $-0,556$ & 101,854 & 75,066 \\
& & $\mathrm{~S}$ & $-0,952$ & $-0,431$ & 103,533 & 3,654 \\
imazetaphyr & \multirow{2}{*}{1,985} & $\mathrm{R}$ & $-1,027$ & 1,780 & 103,800 & 20,048 \\
& & $\mathrm{~S}$ & $-0,900$ & 0,175 & 102,473 & 10,101 \\
\hline
\end{tabular}

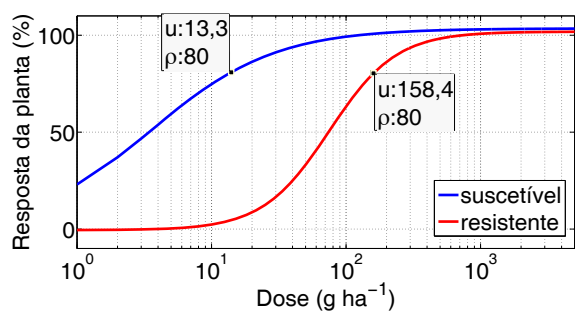

(a) chlorimuron-ethyl

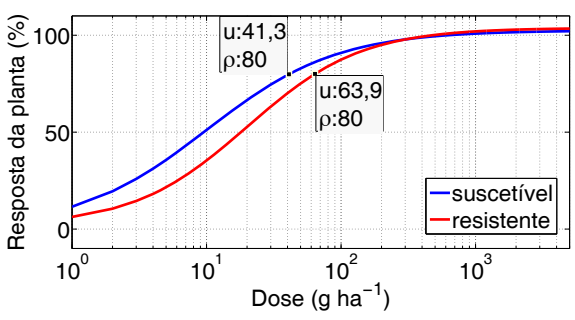

(b) imazetaphyr

Figura 5.6: Curvas de dose-resposta dos herbicidas chlorimuron-ethyl e imazetaphyr utilizando os parâmetros encontrados na Tabela 5.3 e seus respectivos parâmetros $G R_{80}$ de cada curva.

\subsubsection{Simulação do modelo proposto para um herbicida}

Repete-se aqui a simulação do modelo proposto mas com os herbicidas chlorimuronethyl e imazetaphyr. Como antes, a dose será fixada no valor de $G R_{80}$ da curva de dose-resposta suscetível (destacado na Figura 5.2). Resultando no comportamento do banco de sementes, da frequência de alelos e da frequência de indivíduos resistentes esperada e a resposta a dose aplicada de herbicida. Os comportamentos do modelo proposto afetado pelos herbicidas chlorimuron-ethyl e imazetaphyr estão representados 
nas Figuras 5.7 e 5.8:

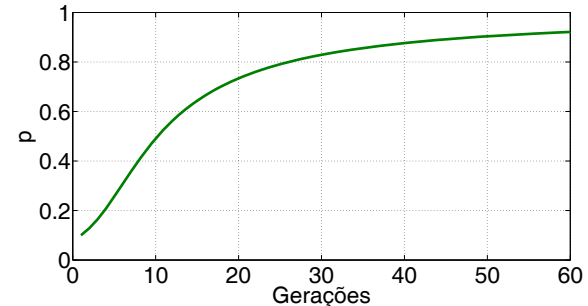

(a)

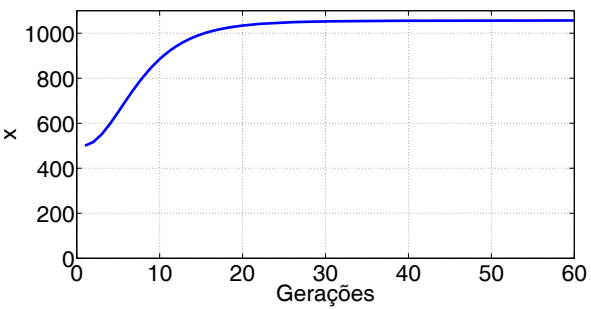

(c)

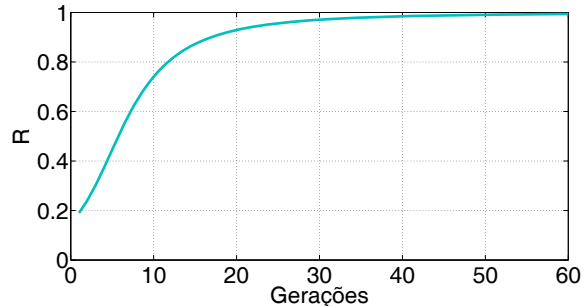

(b)

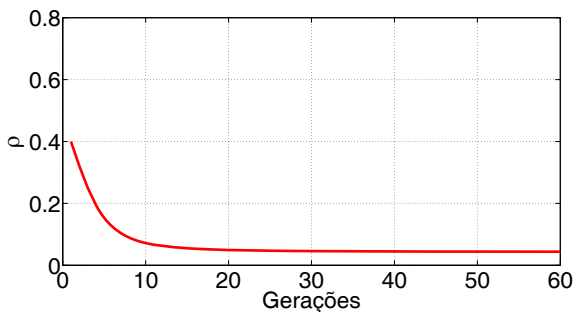

(d)

Figura 5.7: Comportamento genético populacional da Bidens pilosa sob o efeito do herbicida chlorimuronethyl. (a) Frequência do gene resistente, (b) Frequência de indivíduos resistentes, (c) Tamanho do banco de sementes e (d) Eficácia da dose.

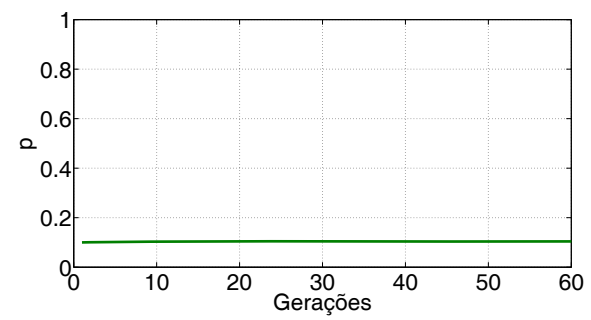

(a)

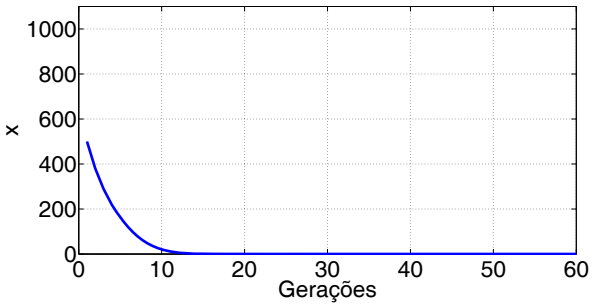

(c)

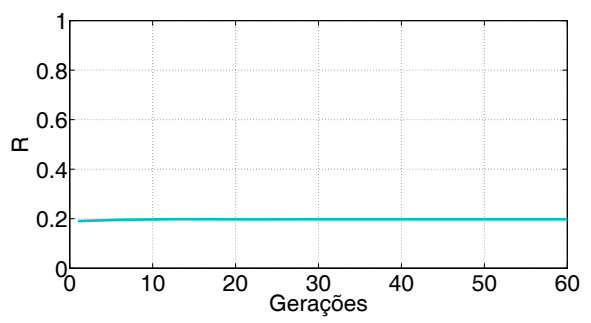

(b)

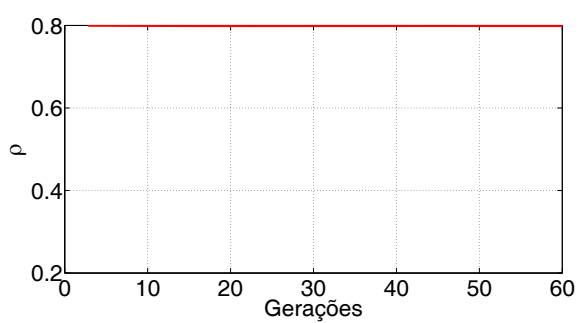

(d)

Figura 5.8: Comportamento genético populacional da Bidens pilosa sob o efeito do herbicida imazetaphyr. (a) Frequência do gene resistente, (b) Frequência de indivíduos resistentes, (c) Tamanho do banco de sementes e (d) Eficácia da dose. 


\subsubsection{Simulação MSBSB e do MCGP para o herbicida chlorimuron- ethyl}

Novamente, com os mesmos dados e parâmetros utilizados nas simulações do modelo proposto para um herbicida são realizadas simulações com o MSBSB e com o MCGP. A análise é feita somente para o herbicida chlorimuron-ethyl.

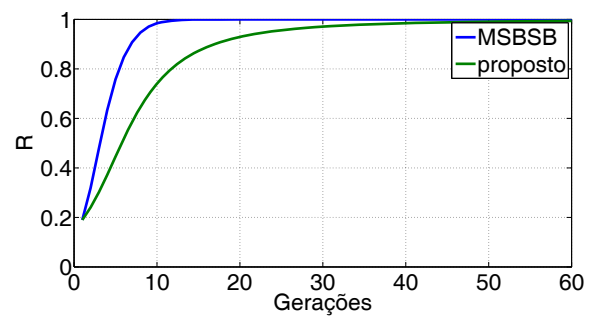

(a)

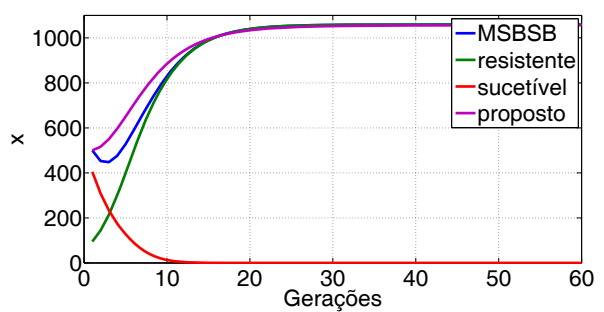

(b)

Figura 5.9: Simulação do MSBSB da Bidens pilosa sob o efeito do herbicida chlorimuron-ethyl. (a) Frequência de indivíduos resistentes e (b) Tamanho do banco de sementes.

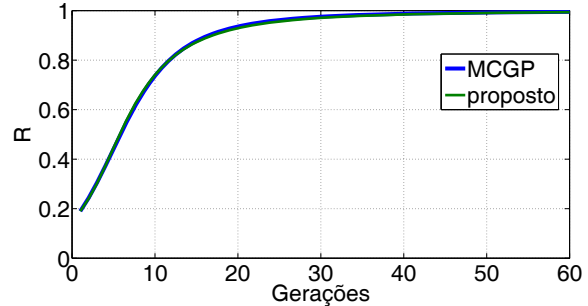

(a)

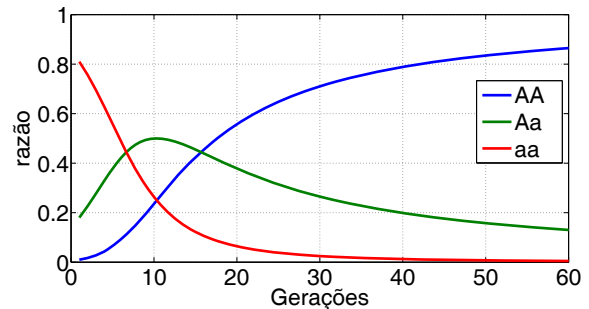

(b)

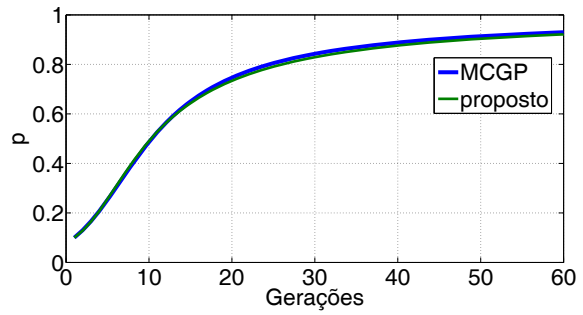

(c)

Figura 5.10: Simulação do MCGP da Bidens pilosa sob o efeito do herbicida chlorimuron-ethyl. (a) Frequência de indivíduos resistentes (b) Razão entre os genótipos e (c) Frequência do gene de resistência.

\subsubsection{Discussão}

O modelo proposto não possui segregação, foi simulado o modelo com segregação por biótipos a fim de comparação. Se comparado ao modelo com segregação do banco 
de sementes por biótipos, ocorre uma diferença na densidade do banco de sementes até a estabilização. A diferença entre os equilíbrios do banco de sementes pode ser explicada pela dependência deste equilíbrio em relação a dose que não ocorre no modelo com segregação do banco de sementes por biótipos.

O modelo de características genéticas da população apresenta resultados semelhantes ao modelo proposto, mas não apresenta a queda seguida de aumento e estabilização do banco de sementes, presente no modelo proposto, ponto importante para estudo da população de plantas daninhas.

As simulações do banco de sementes para um herbicida mostram o comportamento esperado da população de plantas daninhas durante gerações de controle através de herbicida. As simulações mostram uma estabilidade da população com o uso da dose recomendada $G R_{80}$. Ao final do tempo de simulação, o gene responsável pela resistência está presente em toda a população. A maior presença do gene de resistência (e consequentemente de plantas com o biótipo resistente) reduziu a eficácia da dose aplicada.

\subsection{Análise de equilíbrios}

As principais características em qualquer modelo dinâmico são seus pontos de equilíbrio e a natureza de cada um desses pontos. O plano de fase pode descrever o comportamento esperado em quaisquer condições iniciais esperadas. O modelo proposto para uma dose fixada é reescrito na forma:

$$
\begin{aligned}
& x_{t+1}=f\left(x_{t}, p_{t}\right) \\
& p_{t+1}=v\left(x_{t}, p_{t}\right)
\end{aligned}
$$

sujeito a

$$
x(0)=x_{0}, \quad p(0)=p_{0}, \quad x_{0}, p_{0} \in \Re
$$


em que

$f\left(x_{t}, p_{t}\right)=(1-\Psi)(1-\delta) x_{t}+\kappa \exp ^{\frac{\gamma \ln \left(\left(1-\left(c+\frac{d-c}{\left.1+\exp b\left(\ln (u)-\ln \left(G R_{50 t}\left(R_{t}\right)\right)\right)\right]}\right)\right) x^{g} \delta x_{t}\right)}{\mu+\varepsilon \ln \left(\left(1-\left(c+\frac{d-c}{\left.1+\exp b\left(\ln (u)-\ln \left(G R_{50 t}\left(R_{t}\right)\right)\right)\right]}\right)\right) x^{g} \delta x_{t}\right)}}-\eta+\xi$

$v\left(x_{t}, p_{t}\right)=p_{t}+s(u) p_{t} q_{t} \frac{q_{t}}{1+s(u)\left(p_{t}^{2}+2 p_{t} q_{t}\right)} \frac{x_{t}^{n}}{x_{t}}$

sendo $u$ fixo, $x(0)=x_{0}$ e $p(0)=p_{0}$ condições iniciais.

Para analisar os pontos de equilíbrio considere que o sistema dinâmico (5.1)-(5.2) tenha $P=\left(x^{*}, p^{*}\right)$ como ponto fixo, ou seja:

$$
\begin{aligned}
& x^{*}=f\left(x^{*}, p^{*}\right) \\
& p^{*}=v\left(x^{*}, p^{*}\right) .
\end{aligned}
$$

Pode-se, então, determinar todos o os pontos de equilíbrio de (5.1) (5.2) e, em seguida, analisar esses pontos em relação a sua estabilidade. Os pontos de equilibrio encontrados para as diversas doses aplicadas de herbicida são do tipo sela, nó estável e degenerado estável (Monteiro 2002).

Quando ocorre uma baixa população de plantas adultas $\left(y_{t}^{a}<0,5\right)$, o modelo tornase linear:

$$
\begin{aligned}
& x_{t+1}=(1-\Psi)(1-\delta) x_{t} \\
& p_{t+1}=p_{t}
\end{aligned}
$$

com variáveis de estado $\left(x_{t}\right.$ e $\left.p_{t}\right)$ atendendo a condição de restrição $x_{t}^{r}=0$ quando $y_{t}^{a}<0,5$ e os parâmetros $\eta$ e $\xi$ são nulos. Neste caso, o ponto de equílibro é a origem e é do tipo degenerado marginalmente estável, pois os autovalores do sistema $\left(\lambda_{1}=\right.$ $(1-\Psi)(1-\delta)$ e $\left.\lambda_{2}=1\right)$ possuem magnitude menores ou iguais a 1 e os autovalores iguais a 1 são raízes simples do polinômio mínimo do modelo. 


\subsubsection{Bidens subalternans}

Para a análise dos resultados é utilizado os dados de massa verde do modelo de doseresposta da espécie Bidens subalternans com aplicação do herbicida atrazine e nicosulfuron. Os pontos de equilíbrio foram determinados numericamente e encontram-se na Tabela 5.4, juntamente com sua classificação de acordo com os autovalores da matriz Jacobiana correspondente. Nas Figuras 5.11 e 5.12 estão representados o método gráfico utilizado para determinar os pontos de equilíbrio com o atrazine e nas Figuras 5.14 e 5.15 também está representado o mesmo método gráfico, agora com o nicosulfuron. Os planos de fase são apresentados nas Figuras 5.13 (atrazine) e 5.13 (nicosulfuron).

Tabela 5.4: Pontos de equilíbrio do modelo dinâmico para a Bidens subalternans

\begin{tabular}{|c|c|c|c|c|}
\hline Herbicida & Ponto & $\lambda_{1}$ & $\lambda_{2}$ & Tipo de ponto \\
\hline & $(0,0)$ & 0,560 & 1 & degenerado estável \\
\hline atrazine & $(111,1)$ & 1,090 & 0,0025 & sela \\
\hline \multirow[t]{2}{*}{$1889,6 g h a^{-1}$} & $(312,1)$ & 0,924 & 0,0025 & nó estável \\
\hline & $(0,0)$ & 0,560 & 1 & degenerado estável \\
\hline nicosulfuron & $(66,1)$ & 1,187 & 0,0020 & sela \\
\hline $51,725 g h a^{-1}$ & $(463,1)$ & 0,869 & 0,0020 & nó estável \\
\hline
\end{tabular}




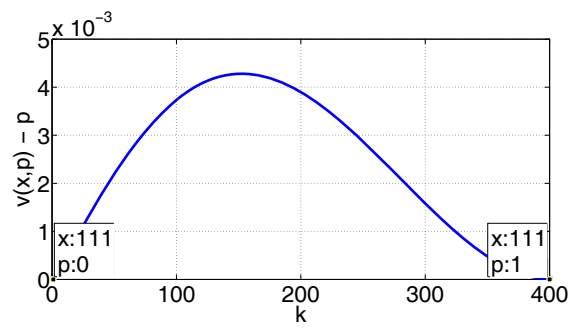

(a)

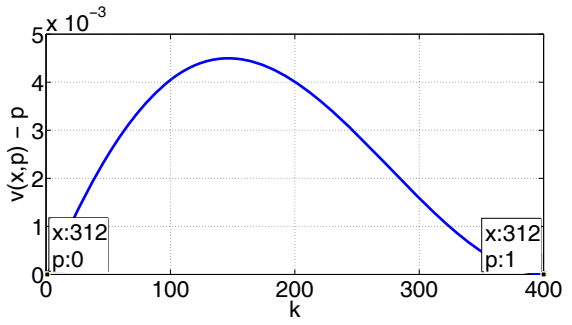

(b)

Figura 5.11: Função $v(x, p)-p$ na região dos pontos de equilíbrio, com (a) $x=111$ e (b) $x=312$ para herbicida atrazine.

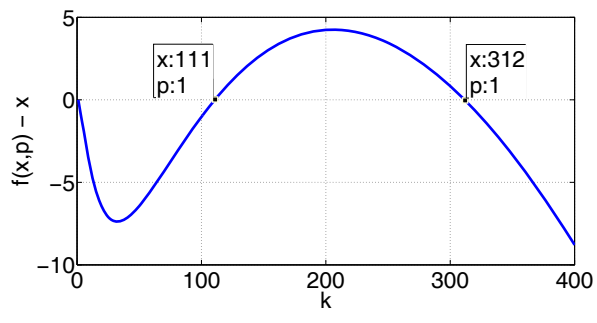

(a)

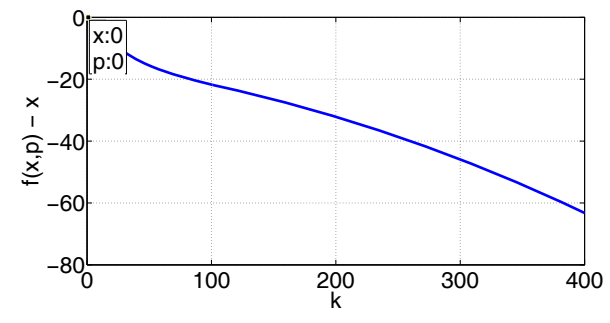

(b)

Figura 5.12: Função $f(x, p)-x$ na região dos pontos de equilíbrio, com (a) $p=1$ e (b) $p=0$ para herbicida atrazine.

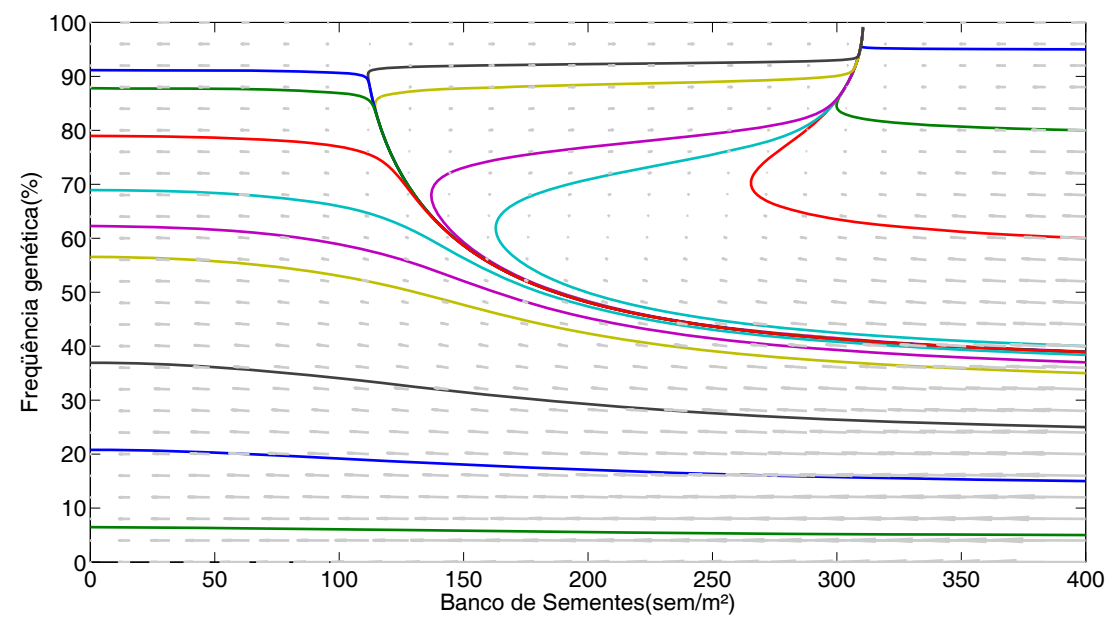

Figura 5.13: Plano de fase do modelo com uso do herbicida atrazine na dose $1889,6 g h a^{-1}$. 


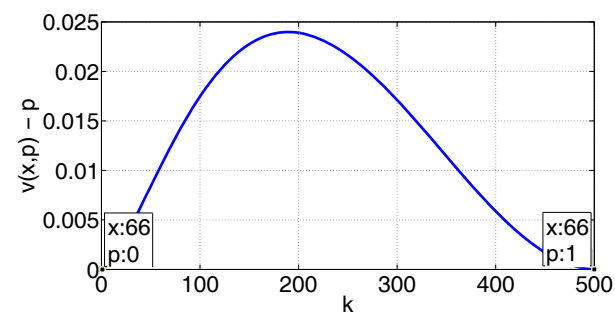

(a)

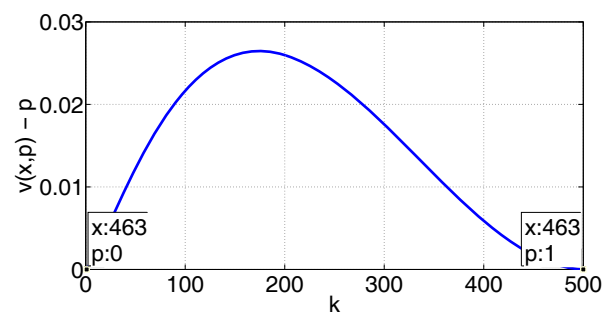

(b)

Figura 5.14: Função $v(x, p)-p$ na região dos pontos de equilíbrio, com (a) $x=66$ e (b) $x=463$ para o herbicida nicosulfuron.

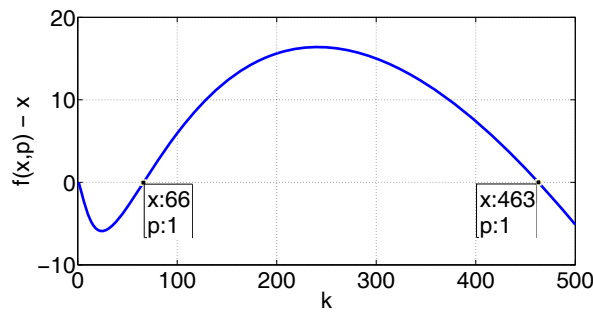

(a)

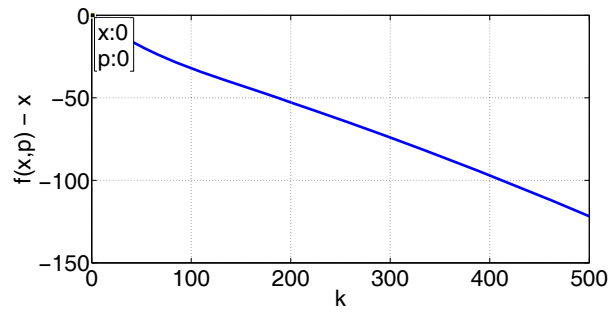

(b)

Figura 5.15: Função $f(x, p)-x$ na região dos pontos de equilíbrio, com (a) $p=1$ e (b) $p=0$ para o herbicida nicosulfuron.

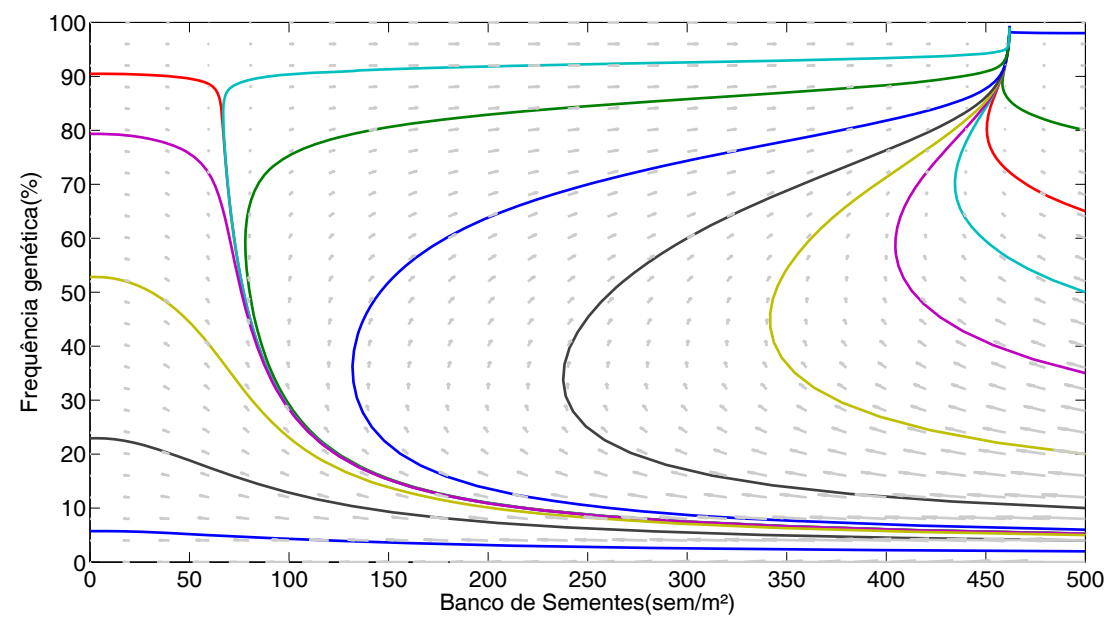

Figura 5.16: Plano de fase do modelo com uso do herbicida nicosulfuron na dose $51,725 g h a^{-1}$. 


\subsubsection{Bidens pilosa}

Para a análise dos resultados é utilizado os dados de massa verde do modelo de doseresposta da espécie Bidens pilosa com aplicação do herbicida chlorimuron-ethyl na dose $G R_{80}=13,3 g h a^{-1}$ e imazetaphyr nas doses $41,3 g h a^{-1}, 20 g h a^{-1}$. Pontos de equilíbrio foram determinados numericamente e encontram-se na Tabela 5.5, juntamente com sua classificação de acordo com os autovalores da matriz Jacobiana correspondente. Os parâmetros populacionais são os mesmos utilizados nas simulações. Nas Figuras 5.17 e 5.18 está representado o método gráfico utilizado para determinar os pontos de equilíbrio com o herbicida chlorimuron-ethyl, o mesmo método gráfico é representado nas Figuras 5.20, 5.22, 5.23, 5.25 e 5.26 com o herbicida imazetaphyr. Os planos de fase são representados nas Figuras 5.19 (chlorimuron-ethyl), 5.21, 5.24 e 5.27 (nicosulfuron em diferentes doses).

Tabela 5.5: Pontos de equilíbrio do modelo dinâmico para Bidens pilosa

\begin{tabular}{lcccl}
\hline Herbicida & Ponto & $\lambda_{1}$ & $\lambda_{2}$ & Tipo de ponto \\
\hline & $(0,0)$ & 0,560 & 1 & degenerado estável \\
chlorimuron-ethyl & $(16,1)$ & 1,491 & 0,0009 & sela \\
$13,3 g h a^{-1}$ & $(1057,1)$ & 0,768 & 0,0009 & nó estável \\
\hline nicosulfuron & $(0,0)$ & 0,560 & 1 & degenerado estável \\
$41,3 g h a^{-1}$ & & & & \\
\hline & $(0,0)$ & 0,560 & 1 & degenerado estável \\
nicosulfuron & $(84,1)$ & 1,142 & 0,0017 & sela \\
$20 g h a^{-1}$ & $(389,1)$ & 0,895 & 0,0017 & nó estável \\
\hline & $(0,0)$ & 0,560 & 1 & degenerado estável \\
nicosulfuron & $(52,1)$ & 1,234 & 0,0017 & sela \\
$15 g h a^{-1}$ & $(545,1)$ & 0,847 & 0,0017 & nó estável \\
\hline
\end{tabular}

Diferentes doses alteram os equilíbrios do modelo. Comparando a Figura $5.22 \mathrm{com}$ a Figura 5.25 e a Figura 5.23 com a Figura 5.26, nota-se a alteração da posição dos equilíbrios do modelo, já nas Figuras 5.24 e 5.27 é possível observar que não houve alteração na natureza destes equilíbrios. 


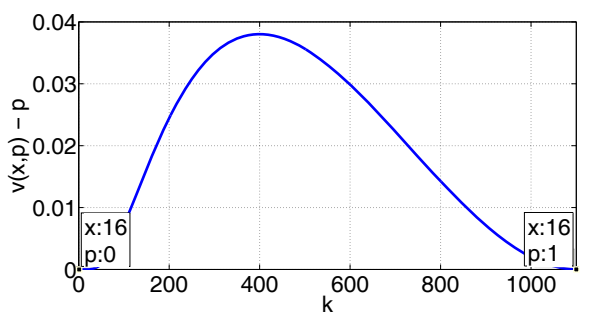

(a)

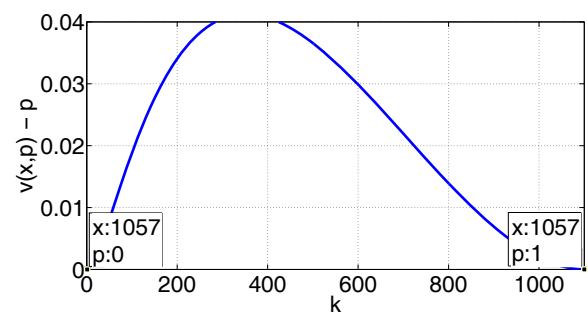

(b)

Figura 5.17: Função $v(x, p)-p$ na região dos pontos de equilíbrio, com (a) $x=16$ e (b) $x=1057$ para o herbicida chlorimuron-ethyl.

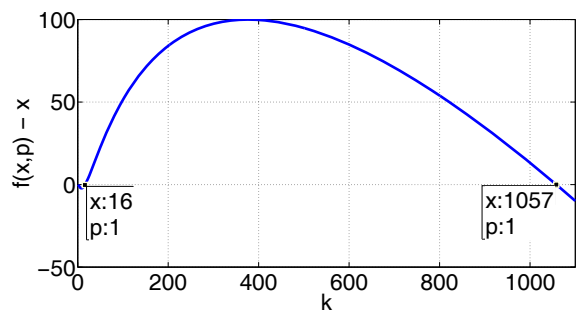

(a)

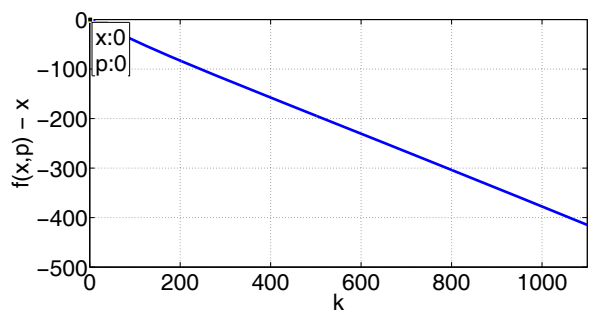

(b)

Figura 5.18: Função $f(x, p)-x$ na região dos pontos de equilíbrio, com (a) $p=1$ e (b) $p=0$ para o herbicida chlorimuron-ethyl.

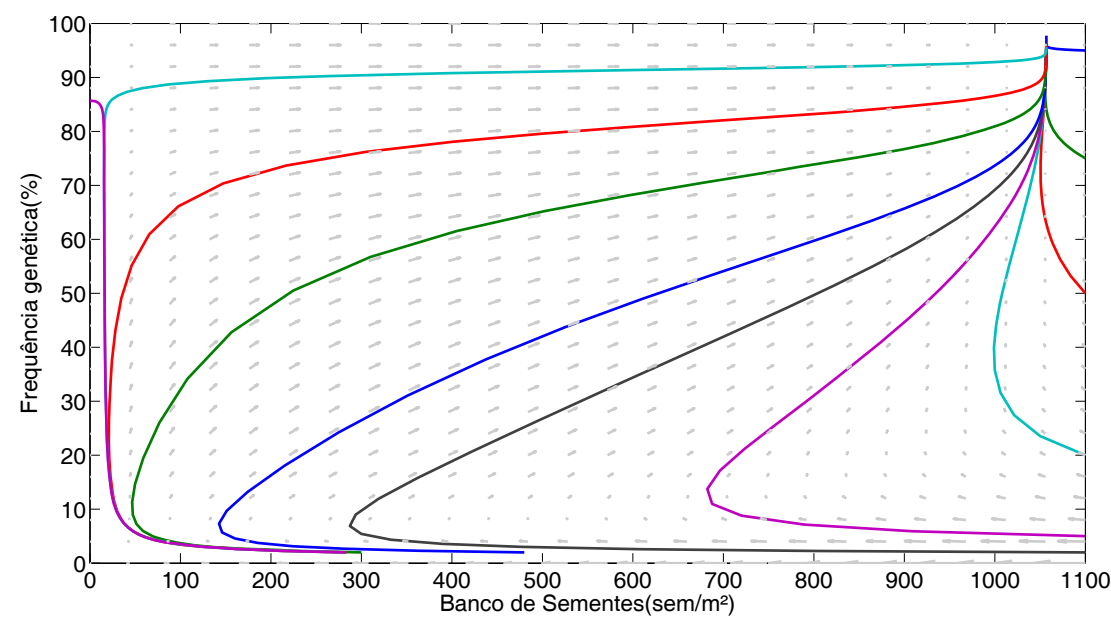

Figura 5.19: Plano de fase do modelo com uso do herbicida chlorimuron-ethyl na dose $13,3 g h a^{-1}$. 


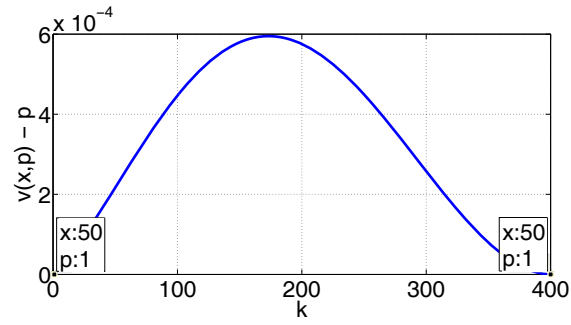

(a)

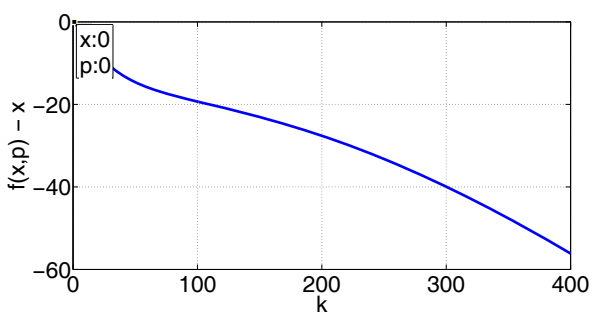

(b)

Figura 5.20: (a) Função $v(x, p)-p$ na região dos pontos de equilíbrio, com $x=50$. (b) Função $f(x, p)-x$ na região dos pontos de equilíbrio, com $p=1$ para o herbicida imazetaphyr na dose $41,3 g h a^{-1}$.

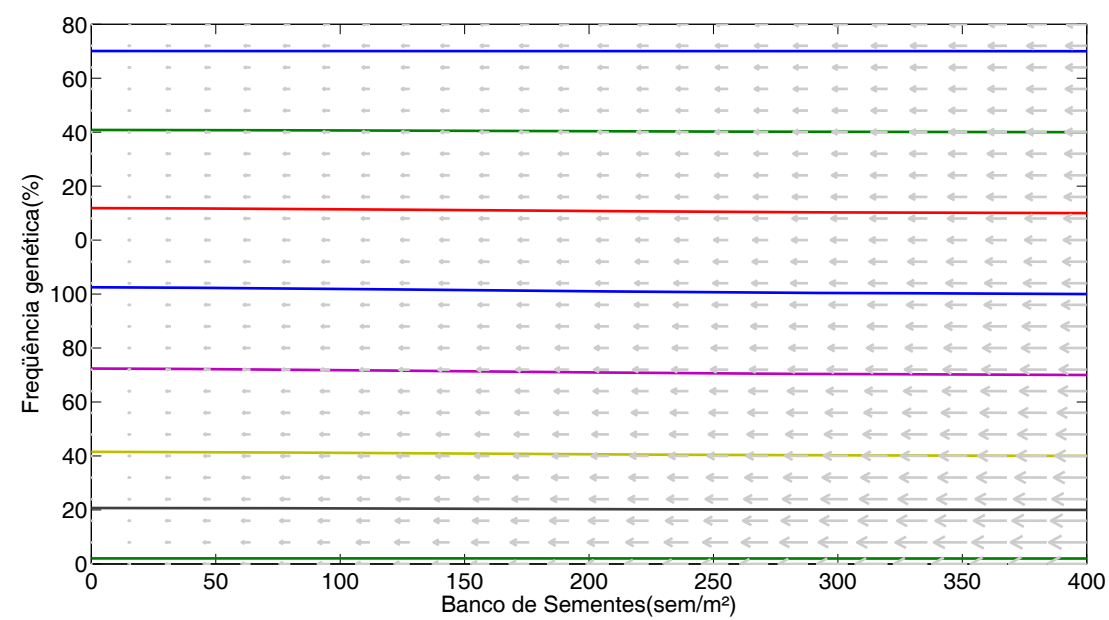

Figura 5.21: Plano de fase do modelo com uso do herbicida imazetaphyr na dose $41,3 g h a^{-1}$. 


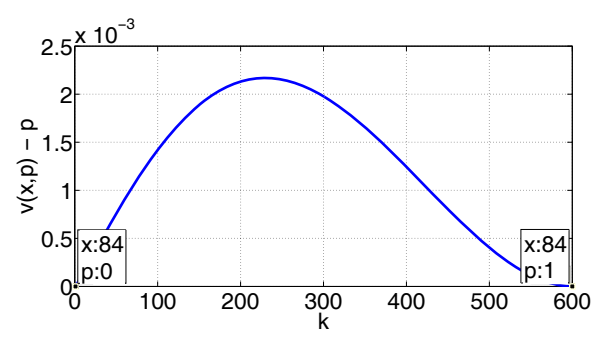

(a)

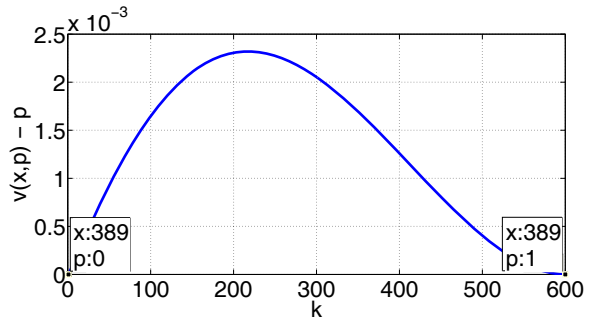

(b)

Figura 5.22: Função $v(x, p)-p$ na região dos pontos de equilíbrio, com (a) $x=84$ e (b) $x=389$ para o herbicida imazetaphyr na dose $20 g h a^{-1}$.

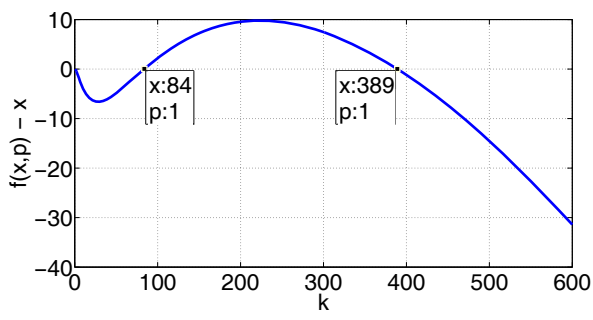

(a)

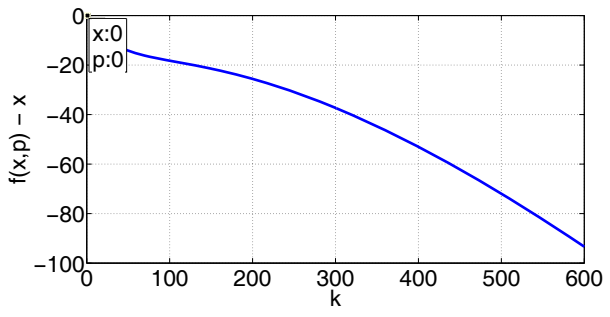

(b)

Figura 5.23: Função $f(x, p)-x$ na região dos pontos de equilíbrio, com (a) $p=1$ e (b) $p=0$ para o herbicida imazetaphyr na dose $20 g h a^{-1}$.

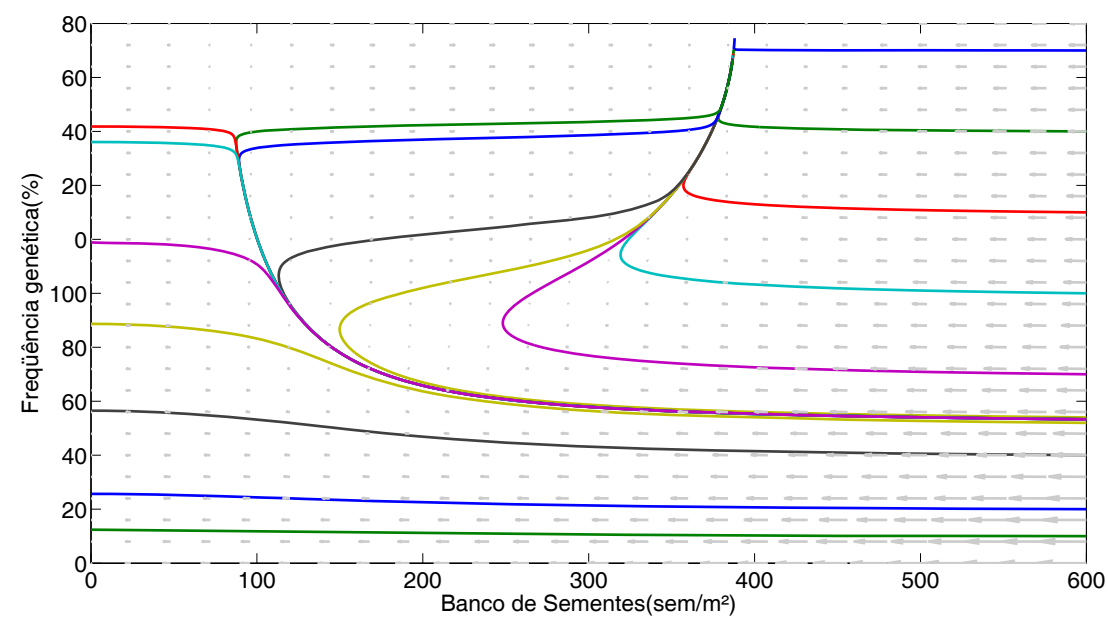

Figura 5.24: Plano de fase do modelo com uso do herbicida imazetaphyr na dose $20 \mathrm{gha} \mathrm{a}^{-1}$. 


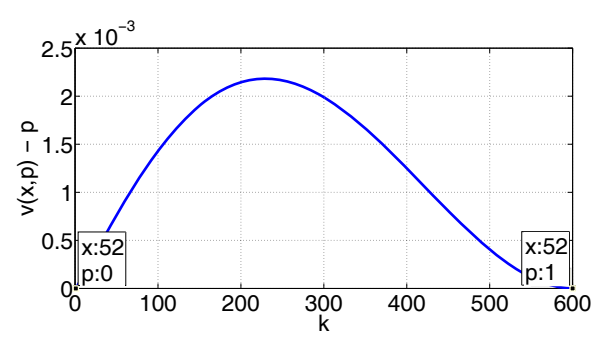

(a)

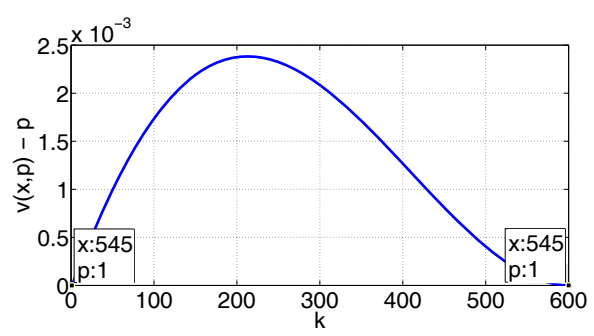

(b)

Figura 5.25: Função $v(x, p)-p$ na região dos pontos de equilíbrio, com (a) $x=52 \mathrm{e}$ (b) $x=545$ para o herbicida imazetaphyr na dose $15 g h a^{-1}$.

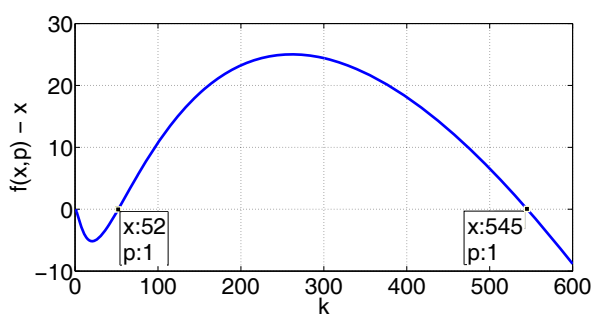

(a)

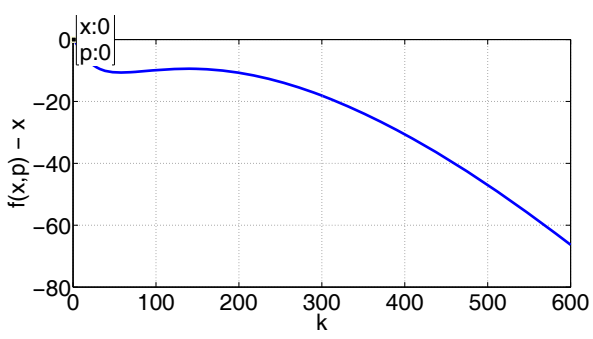

(b)

Figura 5.26: Função $f(x, p)-x$ na região dos pontos de equilíbrio, com (a) $p=1$ e (b) $p=0$ para o herbicida imazetaphyr na dose $15 g h a^{-1}$.

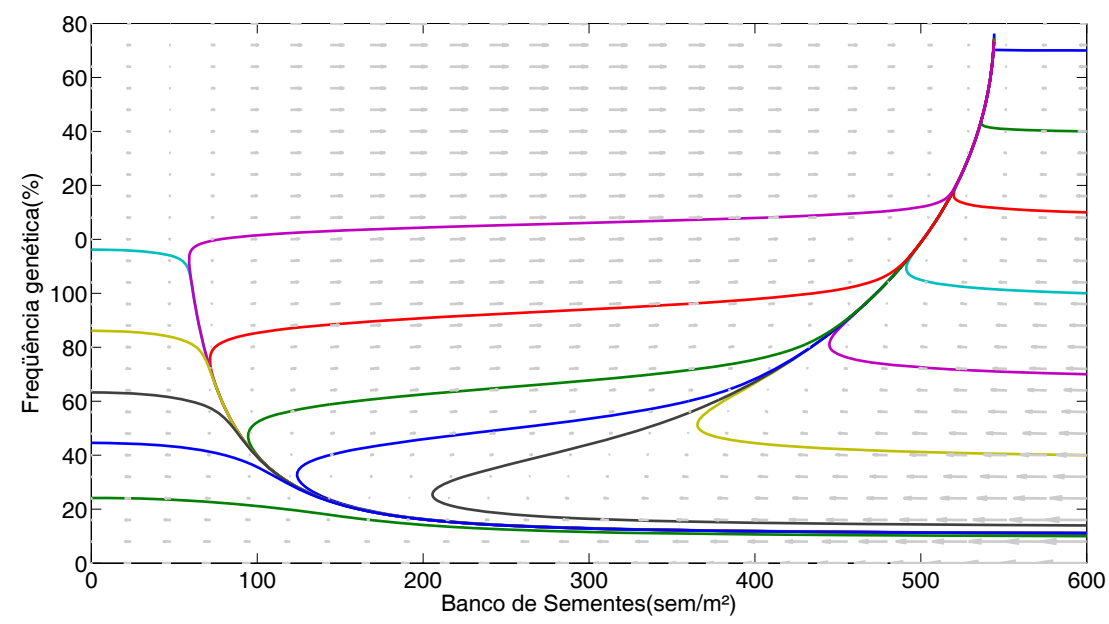

Figura 5.27: Plano de fase do modelo com uso do herbicida imazetaphyr na dose $15 \mathrm{gha} \mathrm{a}^{-1}$. 


\subsubsection{Discussão}

A análise dos equilíbrios do modelo condiz com os resultados apresentados nas simulações. A partir dos planos de fase do modelo é possível realizar um planejamento do modo como será feito o manejo da infestação, definindo a dose que será aplicada.

O estudo de caso do herbicida imazetaphyr foi realizado utilizando 3 diferentes doses, com o objeto de demonstrar como a escolha da dose afeta o comportamento da população. Para o caso da dose $41,3 g h a^{-1}$ de herbicida imazetaphyr o modelo se torna somente linear (5.7), já que todas as plantas adultas são controladas e não há adição de novas sementes ao banco de sementes $\left(x_{t}^{r}=0\right)$. Nos casos das doses $20 g h a^{-1} \mathrm{e}$ $15 g h a^{-1}$ o comportamento é semelhante às demais simulações, o que diferenciam estes dois últimos casos é que pode ser observado que a alteração da dose altera a posição dos equilíbrios do modelo, mas não afeta a natureza destes equilíbrios.

Para comparação, foi simulado o submodelo de recombinação genética, porém não é possível validar se o submodelo corresponde ao comportamento genético de recombinação das plantas estudadas, já que a análise do comportamento genético requer uma análise laboratorial que não pode ser realizada no tempo desta dissertação. A dificuldade em realizar a validação é discutida em Thornby et al. (2009). Os modelos, mesmo sem a validação, podem fornecer um cenário plausível sobre o atual estado da resistência das espécies de plantas daninhas analisadas, baseado no histórico de resistência dessas espécies.

Nas plantas daninhas sob o efeito dos herbicidas estudados observa-se uma dependência do equilíbrio do banco de sementes em relação a dose de herbicida aplicada. Esta dependência se deve ao fato que ocorre ainda variações de mortalidade mesmo em doses muito altas ou muito baixas, seja do biótipo resistente ou suscetível. Esta variação ocorre nas curvas de dose-reposta utilizadas e quanto maior for o parametro b da curva de dose-resposta, menor será a relação de dependência do equilíbrio em relação à dose. Esta dependência apresentada pelo modelo proposto não pode ser comprovada em campo, apenas por experimentos controlados de obtenção da curva de dose-resposta (casa de vegetação). 


\section{Capítulo 6}

\section{Conclusões}

Os estudos de caso apresentados são importantes como forma de investigar como a evolução das plantas daninhas gerou o nível de resistência a herbicidas encontrado atualmente. Seus resultados são condizentes, a velocidade de aparecimento e aumento desta resistência estão dentro do esperado.

A resistência a herbicidas é um dos grandes problemas enfrentados na agricultura. Os esforços na pesquisa de novos herbicidas e métodos de manejo para o controle de infestações têm se mostrado eficazes, porém, este modelo de análise de populações de plantas daninhas resistentes a herbicidas procura dar ao especialista uma nova visão sobre o problema da resistência, através de previsões de estados futuros de uma infestação de plantas daninhas com início de resistência. Também pode auxiliar de forma a reduzir os custos ao produtor, ao possibilitar o planejamento da dose de herbicida a ser aplicada, mesmo com a possibilidade de resistência.

\subsection{Propostas para trabalhos futuros}

No sentido de gerar futuras contribuições, seguem propostas para continuação do trabalho:

- Simulação do modelo para múltiplos herbicidas em casos de resistência múltipla e resistência cruzada. Não foi realizada esta simulação neste trabalho devido a não terem sido identificados nenhum destes dois casos, o que acabou sendo identificado foram dois estudos de caso de plantas resistentes a um herbicida e tolerantes a 
outro herbicida.

- Testes com curvas de dose-resposta diferenciadas. A quantidade de curvas de doseresposta neste trabalho foi limitada, a comprovação do comportamento do modelo proposto utilizando diferentes curvas de dose-resposta é uma grande possibilidade de futuros trabalhos. Diferenciando o herbicida e/ou a planta daninha analisada.

- Descobrir como diferentes técnicas de manejo alteram a dinâmica da infestação por plantas daninhas e consequentemente como alterariam o modelo proposto.

- Adição de fatores de competitividade intra-específica e inter-específica ao modelo proposto, fatores estes que estão presentes em outros modelos da literatura.

- Adição de fatores de migração ao modelo proposto, também presentes em alguns modelos encontrados na literatura. 


\section{Referências Bibliográficas}

ADEGAS, F.; VOLL, E. E PRETE, C. (2003). Embebição e germinação de sementes de picão-preto (Bidens pilosa), Planta Daninha v.21, n.1, p.21-25.

B. D. MAXWELL, M. L. ROUSH, S. R. R. (1990). Predicting the evolution and dynamics of herbicides resistance in weed populations, Weed Technology v.4, n., p. $2-13$.

BRITTON, N. F. (2003). Essential Mathematical Biology, Springer Undergraduate Mathematics Series, London, UK.

CACHO, O. J. (1999). Dynamic models, externalities and sustainability in agriculture, Working Paper Series in Agricultural and Resource Economics, number 4, University of New England, pp. 1-9.

CHRISTOFFOlETI, P. J. (ED.) (2008). Aspectos de Resistência de Plantas Daninhas a Herbicidas, Associação Brasileira de Ação à Resistência de Plantas Daninhas - HRAC-BR, Piracicaba, SP.

Christoffoleti, P. J.; VICTORIA FIlHO, R. E DA SILVA, C. B. (1994). Resistência de plantas daninhas aos herbicidas, Planta Daninha v.12, n.1, p.13-20.

CROW, J. E KIMURA, M. (1970). An Introduction to Population Genetics Theory, Harper and Row, New York.

DIAS, N. M. P. (2004). Tolerância de espécie de capim-colchão (Diggitaria $s p p)$ a herbicidas na cultura de cana-de açúcar, Dissertação de Mestrado, Escola Superior de Agricultura "Luiz de Queiroz", Universidade de São Paulo, Piracicaba, SP. 
DIGGLE, A. J.; NEVE, P. B. E SMITH, F. P. (2003). Herbicides used in combination can reduce the probability of herbicide resistance in finite weed populations, Weed Research v.43, n.5, p.371-382.

DUKE, S. O. E GRESSEL, J. (2010). Weed genomics advance: A commentary, Pest Management Science v.66, n.1, p.1041.

FIRBANK, L. G. E WATKINSON, A. R. (1985). On the analysis of competition within two species mixtures of plants, Journal of Applied Ecologic v.1, n.22, p.503-517.

FRIEDMAN, W. E. E DIGGLE, P. K. (2011). Charles Darwin and the origins of plant evolutionary developmental biology, The Plant Cell v.23, n.1, p.1194-1207.

GRESSEL, J. (2009). Evolving understanding of the evolution of herbicide resistance, Pest Management Science v.65, n.11, p.1164-1173.

GRESSEL, J. (2011). Foresight project on global food and farming futures global advances in weed management, Journal of Agricultural Science v.149, n.1, p.4753.

GRESSEL, J. E. E SEGEL, L. A. (1990). Herbicide rotations and mixtures: effective strategies to delay resistance, in G. M. B.; H. M. LeBaron e W. K. Moberg (eds), Fundamental and Practical Approaches to Combating Resistance, ACS Symposium Series 421, American Chemical Society, Washington, D. C., pp. 430-451.

GRESSEL, J. E SEGEL, L. A. (1978). The paucity of plants evolving genetic resistance to herbicides: possible reasons and implications, Journal of Theorical Biology v.75, n.3, p.349-371.

GRESSEL, J. E SEGEL, L. A. (1979). Genetic Herbicide Resistance: Projections on Appearance in Weeds and Breeding for it in Crops, Plenum Press, New York.

HAAGE, I. R.; BASTIAANS, L.; KEMPENNAR, C.; SMUTNY, V. E KROPFF, M. (2007). Are pre-spraying growing conditions a major determinant of herbicide efficacy?, Weed Research v.47, n.5, p.415-424.

HARPER, J. L. (1956). The evolution of weeds in relation to resistance to herbicides, 3rd British Weed Control Conference, British Weed Control Council, Farnham, UK, pp. 179-188. 
HRAC (2000). The world of herbicides, website. http://www.hracglobal.com/ Portals/5/moa.gif.

ISEE SYSTEMS (2011). Stella, website. http://www.iseesystems.com/ softwares/Education/StellaSoftware.aspx.

JONES, R. E CACHO, O. J. (2000). A dynamic optimisation model of weed control, Working Paper Series in Agricultural and Resource Economics, number 1, University of New England, pp. 1-17.

KIM, D. S.; MARSHALL, E.; BRAIN, P. E CASELEY, J. (2006). Modelling the effects of sub-lethal doses of herbicide and nitrogen fertilizer on crop weed competition, Weed Research v.46, n.6, p.492-502.

LACERDA, A. E VICTORIA FILHO, R. (2004). Curvas de dose-resposta em espécies de plantas daninhas com uso do herbicida glyphosate, Bragantia v.63, n.1, p.73-79.

LÓPEZ-OVEJERO, R. F.; CARVAlho, S. J. P.; NICOlAi, M.; ABREU, A. G.; GROMBOnE-GUARATINI, M. T.; TOLEDO, R. E. B. E CHRISTOFFOLETI, P. J. (2006). Resistence and differential susceptibility of Bidens pilosa and B. subalternans biotypes to ALS-inhibiting herbicides, Scientia Agricola v.63, n.2, p.139-145.

MAY, R. M. E DOBSON, A. P. (1986). Population dynamics and the rate of evolution of pesticide resistance, in N. R. C. Committee on Strategies for the Management of Pesticide Resistant Pest Populations (ed.), Pesticide Resistance: Strategies and Tactics for Management, National Academic Press, Washington, D.C., pp. 170-193.

MENNE, H. (2005). Classification of herbicides according to mode of action, website. http://www.hracglobal.com/Publications/ ClassificationofHerbicideModeofAction/tabid/222/Default.aspx.

MEROTTO, A. J.; JASIENIUK, M.; OSUNA, M.; FERRERO, F. V. A. E FICHER, A. (2009). Cross-resistance to herbicides of five ALS-inhibiting groups and sequencing of the ALS gene in Cyperus difformis l., Agricultural and Food Chemistry v.57, n.4, p.1389-1398.

MONTEIRO, L. H. A. (2002). Sistemas Dinâmicos, Editora Livraria da Física, São Paulo, SP. 
MOSS, S. (1999). Detecting herbicide resistance, website. http://www. hracglobal. com/Publications//DetectingHerbicideResistance/tabid/229/Default. aspx.

NEVE, P. (2008). Simulation modelling to understand the evolution and management of glyphosate resistance in weeds, Pest Management Science v.64, n.4, p.392-401.

NEVE, P.; DIGGLE, A. J.; SMITH, F. P. E POWLES, S. B. (2003). Simulating evolution of glyphosate resistance in Lolium rigidum I: population biology of a rare resistance trait, Weed Research v.43, n.6, p.404-417.

PELEG, M.; NORMAND, M. D. E DAMRAU, E. (1997). Mathematical interpretation os dose-response curves, Bulletin of Mathematical Biology v.59, n.4, p.747-761.

RIZZARDI, M. A. E FLECK, N. (2004). Dose economicamente ótima de acifluorfen + bentazol para controle de picão preto e guanxuma em soja, Planta Daninha v.22, n.1, p.117-125.

RYAN, G. F. (1970). Resistance of common groundsel to simazine and atrazine, Weed Science v.18, n.5, p.614-616.

SEEFELDT, S. S.; JENSEN, J. E. E FUERST, E. P. (1995). Log-logistic analysis of herbicide dose-response relationships, Weed Technology v.9, n.1, p.218-227.

SMITH, M.; TAKEUCHI, K.; ANDERSON, G.; WARE, G.; MC-CLURE, H.; RAYBOURNE, R.; MYTLE, N. E DOYLE, M. P. (2008). Dose-response model for listeria monocytogenes-induced stillbirths in nonhuman primates, Infection \& Immunity v.76, n.2, p.726-731.

STREIBIG, J. C. E KUDSK, P. (1993). Herbicide Bioassays, CRC Press, Boca Raton, FL.

ThORNBY, D.; DIGGLE, A. J. E WALKER, S. R. (2009). Real-world recommendations: Do limits to validation constrain model usefulness?, World IMACS Congress and MODSIM09 International Congress on Modelling and Simulation: Interfacing Modelling and Simulation with Mathematical and Computacional Sciences, Modelling and Simulation Society of Australia and International Association for Mathematics and Computers in Simulation, Carns, Australia, pp. 609-615. 
TIND, T.; MAThieSEN, T. J.; JENSEN, J. E.; RITZ, C. E STREIBIG, J. C. (2009). Using a selectivity index to evaluate logarithmic spraying in grass seed crops, Pest Management Science v.65, n.11, p.1257-1262.

TRANEL, P. J. E WRIGHT, T. R. (2002). Resistance of weeds to ALS-inhibiting herbicides: What have we learned?, Weed Science v.50, n.6, p.700-712.

VARGAS, L.; PEIXOTO, C. M. E ROMAN, E. S. (2006). Manejo de plantas daninhas na cultura do milho, website. http://www. cnpt. embrapa.br/biblio/do/p-do61. pdf.

VIDAL, R. A. E FLECK, N. G. (1997). Three weed species with confirmed resistance to herbicides in Brazil, $37^{\circ}$ Meeting of the Weed Science Society of America, Orlando, USA, p. 100.

WEEDSCIENCE (2009). Herbicide resistant weeds summary table, website. http: //www. weedscience.org/summary/MOASummary.asp.

WRIGHT, S. (1972). Coefficients of inbreeding and relationship, American Naturalist v.56, n.1, p.330-338.

WRIGHT, S. (1984). Evolution and the Genetics of Populations: Genetics and Biometric Foundations, University of Chicago Press, Chicago, IL. 